\title{
Foundations For Military Intervention in the United States*
}

\author{
David E. Engdahl**
}

\section{INTRODUCTION}

To the conscience of the nation that fancies itself the world's greatest democracy, the idea of military intrusion into the affairs of civil government is profoundly repugnant. In 1972, for example, the United States Supreme Court, through Chief Justice Burger, had occasion to recall "the traditional and strong resistance of Americans to any military intrusion into civilian affairs. That tradition has deep roots in our history . . .."1 Again in 1974, the same Chief Justice observed on behalf of the Court that even where some form of government force is warranted, "the decision to invoke military power has traditionally been viewed with suspicion and skepticism since it often involves the temporary suspension of some of our most cherished rights-government by elected civilian leaders, freedom of expression, of assembly and association."2 The case in which the latter statement was made involved the use of state military forces to disperse a crowd and execute state law. This article is not concerned with state military forces; its concern is with the national armed forces of the United States. However, the tradition, and indeed the law, recalled by Chief Justice Burger is even more clearly "suspicious" and "resistant" with regard to intrusions of the national military than with regard to the modest military establishments of the states.

Military intervention can take many forms. It would be an unwarranted extravagance to suggest that the United States

- This article will also appear as part of a symposium, MLITARY INTERVENTION in Democratic Societies: Law Policy and Practice in Great Britain and the United States, edited by P. Rowe and C. J. Whelan to be published in late 1984 by Croom Helm.

** Professor of Law, University of Puget Sound School of Law. LL.B., 1964, University of Kansas; S.J.D., 1969, University of Michigan.

1. Laird v. Tatum, 408 U.S. 1, 15 (1972).

2. Scheuer v. Rhodes, 416 U.S. 232, 246 (1974). 
stands in risk of a military coup d'etat. It would also be extreme to suggest that any widespread imposition of military government, even at the instance of legitimate civilian officials themselves, is probable today. The point of conscience-and of law-which Chief Justice Burger's comments address, however, most significantly pertains to forms of military intervention far short of forceful or invited military takeover.

The execution, or enforcement, of civilian laws by military troops, which often but not exclusively is associated with riots and other civil disorders, is another form of military intervention into civilian affairs. With regard to such intervention, Chief Justice Burger's statements actually understate the force of tradition and conscience embodied in American law. The Chief Justice noted that such "law enforcement" use of military power often "involves" the "suspension" of cherished rights. The more accurate proposition is that military enforcement of civilian law is itself a displacement or "suspension" of civilian process, impermissible per se even apart from any further consequences it might entail.

More than a century ago, in Ex parte Milligan, s the Supreme Court without dissent rejected the contention that the national military could be used as an alternative to civilian measures and procedures to enforce the law even in times of stress. The Court acknowledged that where civilian authority has actually been overthrown-the civil administration deposed, and the civil courts closed-actual and present necessity compels reliance upon the military until civil authority is restored." In such circumstances, however, it is some hostile force that has accomplished the displacement of civilian authority. There is absolutely no lawful power in any branch of the government itself to supersede ordinary civilian authority or suspend any safeguard of the Constitution (except that the privilege of the writ of habeas corpus can be suspended as the Constitution itself prescribes). ${ }^{\circ}$

3. 71 U.S. (4 Wall.) 2 (1866).

4. Id. at 127.

5. U.S. Consr. art. I, \& 9, cl. 2; Ex parte Milligan, 71 U.S. (4 Wall.) at 125. The opinion of the Court was written by Justice Davis and joined by four other Justices. The Chief Justice wrote a concurring opinion, joined by the remaining three Justices, which would countenance resort to military action "where ordinary law no longer adequately secures public safety and private rights," but only "in times of insurrection or invasion, or of civil or foreign war," and even then only when authorized by Congress, "or temporarily, when the action of Congress cannot be invited, and in the case of justifying and 
Although the facts of the Milligan case involved an individual who had been not only sought out, seized, and confined by soldiers, but also thereafter convicted and sentenced by a military tribunal, the principle proclaimed by the Supreme Court pertains not only to military trial and punishment but equally to military measures of law enforcement short of trial. During the Civil War period, Union troops had been employed on countless occasions in the loyal Northern states, superseding regular civilian officials to suppress civil disorders arising from opposition to the military draft and protests against arrests of deserters. Soldiers also went about seizing and confining Northern civilians suspected of supporting the Confederacy. Thousands were detained, and many of those were never brought even to a military trial. All this was done under the claimed authority of the President as Commander-in-Chief, relying upon an opinion written in 1861 by United States Attorney General Bates. The Attorney General had opined that, given the existence of an insurrection in the South, the President enjoyed discretionary power to use the armed forces even in the North to do all he felt necessary to execute federal laws there, regardless of whether any civilians apprehended be brought before some tribunal or merely held indefinitely without trial. ${ }^{6}$ Bates thought it sufficient, to answer the argument that such law enforcement action by the military amounted to a suspension of civil law and rights, to recite that the President-a civilian-was Commander-inChief; he reasoned that this was enough to constitute satisfaction of the acknowledged requirement that the military must be kept subordinate to the civil power.

The thesis advanced by Attorney General Bates in 1861 was the thesis advanced by his successor on the government's behalf in the Milligan case when it was argued in 1866. The rationale the Court used in Milligan for rejecting that particular application of Bates's thesis, reaches and discredits the whole.

Nevertheless, for several years after the Milligan decision,

excusing peril, by the President." Ex parte Milligan, 71 U.S. (4 Wall.) at 142.

6. 10 Op. Att'y Gen. 74, 83-84 (1861).

7. Id. at 79. The historical background of the Commander-in-Chief clause is the struggle between Crown and Parliament for control over the military forces in England, culminating in Parliament's disavowal of the power of military command after the Restoration. See 13 Car. 2, stat. 1, ch. 6, \& 1 (1661). The history of the requirement of subordination of the military to the civilian power is quite different, having to do with claimed prerogative power to intrude with military force into the affairs of governance otherwise proceeding according to the laws of the realm. 
flagrant and willful disregard of the constitutional principle the Supreme Court had applied characterized the process of "reconstructing" the South. ${ }^{8}$ It should not seem remarkable, therefore, that during the past several years, despite the above quoted statements of Chief Justice Burger and the constitutional doctrine to which those dicta refer, new foundations have been laid for military intervention in the United States.

In 1972, the Nixon administration promulgated a set of new "Civil Disturbance Regulations" claiming color of legality for very substantial potential military intrusions into the realm of domestic civil government. ${ }^{\circ}$ The 1972 Regulations took the place of others first devised in 1968 during the Johnson administration, ${ }^{10}$ which themselves had been objectionable on some points of law; but novel provisions in the new Regulations dramatically increased the potential for domestic use of the national military while at the same time substantially reducing prior safeguards against abuse. Then, a year later, the Nixon administration employed the military in law enforcement in a situation which not even those indulgent new Regulations had contemplated. ${ }^{11}$ It would have been notable enough if these events were merely manifestations of the militaristic aura which shrouded that particular administration even to its last days. ${ }^{12}$ However, the 1972

8. See infra text accompanying notes 100-21.

9. Employment of Military Resources in the Event of Civil Disturbances, 37 Fed. Reg. 3637 (1972), 32 C.F.R. $\$ 215$ (1981).

10. 33 Fed. Reg. 9339 (1968). These earlier regulations were discontinued in 1971, see 36 Fed. Reg. 21339 (1971). Meanwhile, regulations entitled Employment of Troops in Aid of Civil Authorities were promulgated at 34 Fed. Reg. 14126 (1969), 32 C.F.R. $\$ 501$ (1981).

11. See infra text accompanying notes 233-34.

12. During the final two weeks of President Nixon's term of office, before his resignation, there was enough apprehension concerning possible untoward use of military units, either against Congress (which was considering impeachment) or otherwise, that the Secretary of Defense initiated extraordinary measures to closely oversee the military lines of command and to ensure that any possible irregular White House orders would not be obeyed. Pentagon Kept Tight Rein in Last Days of Nixon Rule, N.Y. Times, Aug. 25, 1974, at 1, col. 3; Military Coup Fears Denied, Wash. Post, Aug. 27, 1974, at A4, col. 4.

The team of advisors counselling Gerald Ford on matters of transition as he succeeded to the presidency in Nixon's stead urged a cutback in the military influence at the White House, which the transition team perceived had become excessive under Nixon. Transition Team Urged Military Influence Curb, Wash. Post, Sept. 16, 1974, at A2, col. 3. The Army General, Alexander Haig, who had been President Nixon's White House Chief of Staff since May, 1973, and who was identified by Ford's transition team as of particular concern, had until that assignment served briefly as Vice Chief of Staff of the Army. It was in that capacity during February, March, and April, 1973, that General 
Civil Disturbance Regulations have remained in force through three subsequent administrations without any modification; and Justice Department lawyers have continued all this time to defend those responsible for the 1973 use of the military even beyond what those Regulations allow. Moreover, in March, 1982, the Department of Defense issued new regulations entitled "DOD Cooperation With Civilian Law Enforcement Officials,"1s which rely upon and reassert the sweeping claims of executive prerogative for military intervention asserted in the Civil Disturbance Regulations.

Thus, notwithstanding the statements from the judiciary, within little more than a decade the executive branch of the United States government has consolidated the old, and added several new, foundations for military intervention in the United States. It would be idle for a legal scholar to speculate whether any edifice of oppression is likely to be built upon these foundations, whether soon or later in time. A sufficient task for the legal scholar is to disclose that the foundations, although faulty, indeed are there; to explain how those foundations came to be laid; and, to show that they have no footing on the bedrock of our law. ${ }^{14}$

Haig had been a principal participant in planning and supervising the extraordinary episode of military intervention mentioned supra in the text accompanying footnote 11 and discussed much later in this article. A year earlier, Haig had been Deputy to the Assistant to the President for National Security Affairs (Henry Kissinger) at the time when the new Civil Disturbance Regulations were being prepared, although it is not public knowledge whether or to what extent he might have been involved in their preparation. Subsequently, of course, Haig was appointed NATO Commander. Later retiring from the Army, Haig briefly courted a nomination for the presidency, and then in 1981 became Secretary of State.

13. 32 C.F.R. $\$ 213$ (1982), discussed infra in text accompanying notes $185-90$ and 199-200.

14. Some of the material examined in this article has been previously discussed by this author in earlier publications: Engdahl, Soldiers, Riots and Revolution: The Law and History of Military Troops in Civil Disorders, 57 IowA L. Rev. 1 (1971); Engdahl, Renzo \& Laitos, A Comprehensive Study of the Use of Military Troops in Civil Disorders With Proposals for Legislative Reform, 43 U. CoLo. L. Rzv. 399 (1972); and Engdahl, The New Civil Disturbance Regulations: The Threat of Military Intervention, 49 IND. L. REv. 581 (1974). The thesis of those earlier articles has been endorsed and applied by some other writers, e.g., Meeks, Illegal Law Enforcement: Aiding Civil Authorities in Violation of the Posse Comitatus Act, 70 Mr. L. REv. 83 (Dept. of Army Pamphlet 27-100-70, 1975); Comment, Executive Military Power: A Path to American Dictatorship, 54 NEB. L. Rev. 111 (1975). That thesis has also been extensively criticized in Pye \& Lowell, The Criminal Process During Civil Disorders, 1975 Dukr L.J. 581. Because of the intervening commentary, this author has carefully reeramined the premises and the substance of his views and has concluded that his thesis is thoroughly sound. Specific response to some of the contentions of Pye \& Lowell is made in footnotes 


\section{The Bedrock of Civilian Due Process}

The American colonists of the mid-eighteenth century were British subjects who considered themselves heirs to the liberties that had been won through the struggles of what was then relatively recent English history. Increasingly, however, they came to perceive the king of their time as hostile to the liberties thus claimed. How the facts might have appeared to those across the Atlantic, or how they might be viewed in retrospect by more modern historians, is not relevant to the conceptions that prevailed on these shores at that time, or to the precepts which their convictions led those early Americans to ordain.

The single most inflammatory mark of the tyranny they perceived was the use of the royal military troops contrary to what the Americans believed was allowed by established principles of English law. ${ }^{15}$ Increasingly after 1763, British troops were used instead of civil magistrates and the posse to suppress disorders in the colonies, royal military authority thus effectively superseding or suspending ordinary processes of the law. It could have been no comfort to the colonists that on some occasions the king, whom they considered a tyrant, had indulged similar abuses in the homeland. ${ }^{16}$ Even there, the thesis that such use of the military was illegal received some expression; ${ }^{17}$ in the American colonies, this thesis became an expressed point of rebellion. ${ }^{18}$

In their own written constitutions adopted after independence, the several American states included various provisions designed to preclude such domestic applications of military force. ${ }^{10}$ The weak national government the Americans first created was given no power to maintain an armed force of its own; the Articles of Confederation agreed to by the Continental Con-

where appropriate herein.

15. The history only cursorily surveyed here was extensively discussed and documented by this author in Soldiers, Riots, and Revolution, The Law and History of Military Troops in Civil Disorders, 57 Iowa L. Rev. 1 (1971) [hereinafter cited as Soldiers, Riots, and Revolution]. The reader is urged to resort to that work for fuller exposition.

16. Pye \& Lowell, supra note 14 , at 669 n.268, report statistics concerning civilian casualties from domestic military actions in England between 1740 and 1780, citing G. Rude, The Crowd in History: A Study of Popular Disturbances in France and EngLAND 1730-1848 (1964).

17. See, e.g., W. Jones, Legal Mode of Suppressing RJots (1780).

18. See Soldiers, Riots, and Revolution, supra note 15 , at $26-28$, and the revolutionary era documents quoted infra in the text accompanying notes 39-43.

19. See Soldiers, Riots, and Revolution, supra note 15, at 28-30. 
gress in 1777 and subsequently ratified by the states even prohibited any state from maintaining regular armed forces, "except such number only, as in the judgment of the United States, in Congress assembled, shall be deemed requisite to garrison the forts necessary for the defense of such state. ..."20 They did not wish to be open to assault by alien powers, but the Americans would not countenance any risk of military intervention in domestic civilian affairs-a risk which their own experience with British troops in the late colonial period had taught them to associate with standing armies. They were familiar with riots, mobs, and disorders; but they considered any military response to such exigencies intolerable, and resolved to rely instead upon civil magistrates, the traditional posse, and the process of civilian law.

The new Constitution proposed in 1787 met with opposition on several grounds; but no feature of the new plan was more controversial than the provision it made for the maintenance of a national army, ${ }^{21}$ even though such maintenance was to be at the discretion of the legislative branch to be exercised at least each second year. ${ }^{22}$ The specter of military law enforcement and military suppression of disorders had not lost its horror. When the Pennsylvania state ratifying convention met, one third of the delegates demanded amendments, several of which were aimed at the specter of military law enforcement; voted against ratifcation when the amendments were refused by the majority; and, afterwards published and widely disseminated a pamphlet denouncing the Constitution as countenancing execution of the laws by military force. ${ }^{23}$ Hamilton and Madison rushed to

20. Articles or Confederation art. VI, cl. 4.

21. See Soldiers, Riots, and Revolution, supra note 15, at 35-39.

22. "The Congress shall have Power ... To raise and support Armies, but no Appropriation of Money to that Use shall be for a longer Term than two Years." U.S. Const., art. I, § 8, cl. 12.

23. The Address and Reasons of Dissent of the Minority of the Convention of the State of Pennsyluania to Their Constituents, 1787, in 2 B. Schwartz, The BrLl op Rights: A DocumentaRy History 662, 671 (1971). The amendments they had proposed to remedy this evil would have: (a) forbidden standing armies during peace, no. 7; (b) reserved principal power over the militia to the states and restricted their availability for use outside their home states, no. 11; (c) provided, as nearly all of the state constitutions did, that "the military shall be kept under strict subordination to, and be governed by the civil powers," no. 7; and (d) added a truncated version of the anti-military guarantee of Chapter 39 of Magna Carta (see infra text accompanying note 30) providing "that no man be deprived of his liberty, except by the law of the land or the judgment of his peers," no. 3, 2 B. Schwartz, id. at 665. 
answer this denunciation in their Federalist Papers, insisting that no use of military force was contemplated for situations short of armed insurrection. ${ }^{24}$ Ratification in Delaware, New Jersey, Georgia, Connecticut, and Massachusetts was accomplished without major excitement over the military law enforcement issue; but in April, May, and June, 1788, that issue was partly responsible for the opposition of one third of the delegates in South Carolina and caused several proposed amendments to accompany Maryland's and New Hampshire's ratifications. $^{23}$ Madison's own state, Virginia, accompanied its

24. Responding in three successive numbers of The Federalist (Nos. 27, 28, 29) to the Pennsylvanians' accusation that the proposed Constitution contemplated the new national government employing "the aid of a military force to execute the laws," Alexander Hamilton insisted that the provision for military force was only for seditions and insurrections, "to preserve the peace of the community and to maintain the just authority of the laws against those violent invasions of them which amount to insurrections and rebellions." The Federalist No. 28, at 178-79 (A. Hamilton) (C. Rossiter ed. 1961) (emphasis added). Non-military means, Hamilton insisted, were available and would be sufficient in all except situations of insurrection: because federal law would be supreme and operate directly upon the citizens, binding local officials in their dealings with citizens as much as any state law could, the Constitution

would enable the government to employ the ordinary magistracy of each [state], in the execution of its laws. . . . Thus the legislatures, courts, and magistrates of the respective members, will be incorporated into the operations of the national government as far as its just and constitutional authority extends; and will be rendered auxiliary to the enforcement of its laws.

The Federalist No. 27, at 176-77 (A. Hamilton) (C. Rossiter ed. 1961) (emphasis deleted). If this should not be enough to accomplish the execution of federal laws, Hamilton argued, still there would be no cause for recourse to a military expedient, for by virtue of the necessary and proper clause Congress could provide for the use of citizens as a posse comitatus to assist the officers entrusted with execution of the federal laws. The Federalist No. 29, at 183 (A. Hamilton) (C. Rossiter ed. 1961). The military expedient was only provided for "times of insurrection . . . to guard the public against the violence of faction or sedition." Id. at 187.

Discussing in The Federalist No. 43 the "domestic Violence" provision of the guaranty clause, James Madison described it as authorizing the national government "to support the State authority" in the event of "insurrection in a State," instances of "violent factions, flying to arms and tearing a State to pieces;" and he quoted in support of the provision a statement of Montesquieu regarding "a popular insurrection." The FenkralIST No. 43, at 276-77 (J. Madison) (C. Rossiter ed. 1961).

25. As to South Carolina, see the speech of Mr. Dollard, in 2 B. Schwartz supra note 23, at 752-53. New Hampshire proposed prohibiting any standing army in time of peace except upon three-fourths vote of both houses of Congress, no. 10; 2 B. SchwarTz, supra note 23 , at 761 . Miaryland rejected a standing army prohibition, but demanded several others respecting the military, including one prohibiting subjecting the militia to martial law except in time of war, invasion, or rebellion. In support of this the Maryland convention made specific reference to Magna Carta and the rule based upon it recited by Coke, Hale, and Blackstone, see infra note 39, holding that martial law powers could not be employed except in time of war, invasion, or rebellion. 2 B. SchwarTz, supra note 23 , at 734-35. 
ratification with demands for several amendments aimed at the specter of military law enforcement, as did Hamilton's own state of New York. ${ }^{26}$ These demands persuaded Madison that amendments were desirable, and it was he who insistently pressed upon the first Congress the task of preparing amendments to propose to the states. He sought concise phrases to capture the import of those state convention demands he found to have merit. The language which he chose, which Congress approved, and which the states ratified to assuage the fears of military law enforcement was that "[n]o person shall . . . be deprived of life, liberty, or property without due process of law."27

26. Virginia demanded clauses providing: (a) that no standing army be kept in peace except upon two-thirds vote of both houses of Congress, amend. no. 9; (b) "[t]hat, in all cases, the military should be under strict subordination to, and governed by, the civil power," declaration of rights no. 17; (c) "that all power of suspending laws, or the execution of laws, by any authority, without the consent of the representatives of the people in the legislature, is injurious to their rights, and ought not to be exercised," declaration of rights no. 7; and (d) as a more complete recitation of the anti-military guarantee of Chapter 39 of Magna Carta (see infra text accompanying note 30) "that no freeman ought to be taken, imprisoned, or disseized of his freehold, liberties, privileges, or franchises, or outlawed, or exiled, or in any manner destroyed, or deprived of his life, liberty, or property, but by the law of the land," declaration of rights no. 9. 2 B. SchWART2, supra note 23, at 841-43. Virginia also demanded a provision like that demanded by Maryland, see supra note 25; amend. no. 11, 2 B. ScHWARTz, supra note 23 , at 843.

New York prefaced its ratification with a long list of declared rights, which it referred to as "explanations . . . consistent with the said Constitution," and which it expressed confidence would receive "an early and mature Consideration. . . ." Among the "explanatory" provisions thus proposed by New York were: (a) a clause providing "that standing Armies in time of Peace are dangerous to Liberty, and ought not to be kept up, except in Cases of necessity;" (b) a clause like that demanded by Maryland recalling the precept of Coke, Hale and Blackstone, see supra note 25; (c) a clause providing "that at all times, the Military should be under strict subordination to the civil Power;" and (d) a clause similar to Virginia's recitation of the anti-military guarantee of Magna Carta, providing "that no person ought to be taken imprisoned or disseised of his freehold, or be exiled or deprived of his Privileges, Franchises, Life, Liberty or Property but by due process of Law." 2 B. SchwARTz, supra note 23, at 911-14. New York also urged that, pending consideration of these "explanatory" amendments, its militia not be used outside New York for a longer period than six weeks without the consent of the state legislature - a further reflection of apprehensiveness over possible military enforcement of federal law. 2 B. ScHwARTz, supra note 23 , at 914.

27. Madison opposed prohibiting a standing army; but it is clear from The FederalIst Nos. 27-29, 43, supra note 24, that neither he nor Hamilton countenanced military law enforcement (whether by regular army or by militia) except in situations of insurrection. He could not ignore the vigorous demands for some textual provision to ensure that military law enforcement in lesser situations would be precluded, however. As one knowledgeable in the law, he must have been aware that the precept of military subordination to civil powers and the prohibition of prerogative suspension of the laws were but corollaries of the older and more fundamental principle of Chapter 39 of Magna Carta. See infra text accompanying notes $30-43$. Separate statement of the corollaries would be 
No concise set of words could better have comprehended the traditional English prohibition against the use of military force for law enforcement than this phrase guaranteeing "due process of law." Long before the rise of a professional army, able Englishmen had been required to keep arms and to answer, on the one hand, the call of the sheriff as a posse, and on the other hand, the call of the constable or the Earl Marshal to war. ${ }^{28}$ However, very different rules governed their actions in these two different capacities. When men in arms in the year 1381 rose to suppress the mob violence of the Peasants' Revolt, and used measures beyond those allowed by the rules applicable to the civilian sheriff and posse, that recourse to such measures as were allowable only for war was a crime; and the crime would have been punishable had King Richard II not issued a pardon to the overzealous suppressors. The terms of the pardon are significant: those who had employed measures appropriate only to war were pardoned for the acts they had done sans due process de loye, without due process of law. ${ }^{29}$

The pledge of King John by Chapter 39 of Magna Carta in 1215 that no free man would be taken, imprisoned, or destroyed except "by the law of the land," had itself been demanded by

unnecessary if the fundamental principle were affirmed. In the interest of concise statement the redundant verbiage of the thirteenth century charter provision, as elaborately recited in the Virginia and New York proposals, could be excised: to say that neither life, nor liberty, nor property could be touched by military prerogative, was sufficient to say it all. Magna Carta, however, did not foreclose Parliament from authorizing military expedients; and therefore to have used its original phrase, "the law of the land," as the Virginia proposal had, would not have answered the fears that Congress might provide for militia or army execution of the laws. Madison expressly declared that he found the English guarantees deficient precisely in that they did not foreclose Parliamentary abuses; and he was resolved to have limitations as effective against the legislative as against the executive branch. See Madison's speech introducing his proposed amendments, 1 Annals or Cong. 453-54 (J. Gales ed. 1789), reprinted in 2 B. Schwartz, supra note 23 , at 1028-29. Therefore he chose for his concise formulation of the anti-military principle of Chapter 39 of Magna Carta the alternative phrase that had been used in New York's proposed provision: "due process of law." See 2 B. SchwarTz, supra note 23, at 855-56. This suitably adapted the clause, as it appears in the fifth amendment, to bind Congress as well as the executive to civilian processes as distinguished from military expedients in all dealings that might impact the life, liberty, or property of the people.

Closing their eyes to this background of the language chosen by Madison and quietly accepted even by those states which had been most insistent upon effective assurances against military law enforcement, Pye \& Lowell, supra note 14, at 657, blandly assert: "We are aware of no evidence that the due process clause of the fifth amendment was intended to deal at all with the subject of military aid to the civil power." Ignoscunt ut ignarent. See also infra note 44.

28. See Soldiers, Riots, and Revolution, supra note 14, at 3-5.

29. 5 Rich. 2, stat. 1, ch. 5 (1831). 
the barons at Runnymede specifically because the king had theretofore enforced his will by military means in preference to civilian process. King Edward II, a century later, in 1322, used knights in arms to seize and punish some dissident nobles; when it convened at the accession of that king's successor in 1327, Parliament made explicit reference to Chapter 39 of Magna Carta in denouncing King Edward's resort to such military means. ${ }^{30}$

Tudors and the first Stuart monarchs nonetheless claimed a broad prerogative power to deal with their subjects by what:was then called "martial law." This Tudor and Stuart concept of "martial law" prerogative must be distinguished from the law of military discipline applied in the old Court of the Constable and Marshal or the more modern counterpart rules for the discipline of armed forces; and it must be distinguished as well from what might better be called "the law of martial rule" or "military government." The "martial law" power claimed by Tudor and Stuart monarchs included the asserted right to intervene by prerogative in the domestic affairs of the kingdom on grounds of purported necessity, suspending or superseding the ordinary law and its processes, whether to require the quartering of troops in private houses; or to exact so-called "ship money" or other assessments or forced "loans;" or to carry out summary trials and punishments; or to suppress civil disorders with military force. As part of this broad "martial law" prerogative, by the late sixteenth century Lord-Lieutenants under royal commission, with troops assigned to assist them, had become the usual means for suppressing commotions and civil disorders in England, superseding the sheriffs and other regular civil officials. ${ }^{31}$ James I emulated the Tudor example when disorders arose where he had quartered troops awaiting transport abroad. ${ }^{32}$ Under Charles I, the patience of the English with these abuses at last ran out. In 1627 Charles' quartering impositions led to riots and brawls in port towns, which were suppressed with military force under prerogative commissioners on the Tudor model.

30. Thomas Earl of Lancaster's Case, in 1 M. Hale, The History of the Pleas of The Crown 343-46 (1st Am. ed. 1947); Edmund Earl of Kent's Case, in M. Hale, The History of the Common Law of England 40-41 (2d ed. 1716).

31. See Soldiers, Riots, and Revolution, supra note 14, at 9.

32. An example of the military commissions for riot suppression issued by James $I$ is published in 17 Rymer, Foedera, Conventiones, Et Cujuscunque Generis Acta PubLICA 647 (2d ed. 1726). 
These events, and the burdens of financial exactions based upon the same claim of a broad "martial law" prerogative, excited Parliament in 1628 to draw up the Petition of Right, which denounced the whole range of actions taken by virtue of the "martial law" prerogative as contrary to the law of the realm, and specifically, Magna Carta. ${ }^{\text {ss }}$ In the years that followed, the continued exaction of "ship money" fueled burning resentment against King Charles, and his continued claim to prerogative domestic use of troops helped to precipitate the civil wars which commenced in $1642 . .^{34}$

After the Restoration, the repudiation of a prerogative "martial law" power was reaffirmed. ${ }^{35}$ Nevertheless, when it was perceived that James II's keeping of some 30,000 private troops omened a possible return of earlier Stuart abuses, the Glorious Revolution of 1688 and the Bill of Rights of 1689 ousted James and conditioned the maintenance of any standing army within the kindgom upon Parliament's approval. More significantly, addressing the issue of Tudor-Stuart "martial law" prerogative to supersede civil process and execute the laws with military force, the Bill of Rights specifically declared: "That the pretended power of suspending of laws, or the execution of laws, by royal authority without consent of Parliament, is illegal."36

These great events of the seventeenth century firmly settled the principle that the use of the military to enforce law and order is not "due process of law." The Riot Act enacted by Parliament in $1714^{37}$ called for civilian officials and the posse comitatus to disperse mobs and suppress civil disorders, and authorized those civilian personnel to use any degree of force necessary

33. The sweeping significance of the Petition of Right is sadly misstated by Pye \& Lowell. They assert that "[ $t]$ he Petition of Right forbade only the practice of punishing those apprehended during the military suppression of riots by illegal tribunals. It did not affect the ability of the Crown to use the military to suppress riots." Pye \& Lowell, supra note 14, at 668 . Quite the contrary is evident on the face of the Petition. What was declaimed was the whole range of "martial law" prerogative, explicitly including prerogative financial exactions, quartering, and the issuance and execution of the military commissions, "which commissions, and all other of like nature, are wholly and directly contrary to said laws and statutes of this your realm." One thing called for by those commissions was the summary military trial and execution of offenders; but another thing equally called for by those commissions was military suppression of the disorders themselves.

34. See Soldiers, Riots, and Revolution, supra note 14, at 10-14.

35. M. Hale, The History of the Common Law of England 39-40 (2d ed. 1716).

36. 1 W. \& M. 2, ch. 2, decl. 1 (1689).

37. 1 Geo. 1, stat. 2, ch. 5 (1714). 
to accomplish the purpose; but that Act notably made no provision whatsoever for any use of military troops. It is instructive to contrast that 1714 Act concerning riots and civil disorders with a different act passed by Parliament in the very same year. The latter dealt, not with riots or civil disorders, but with "insurrection" or "rebellion" as well as "invasion;" and for these situations, unlike for riots and disorders, it authorized the use of militia. ${ }^{38}$

The foregoing was history as recent to the American colonists as the Great War, the Great Depression, and the New Deal are to Americans today. Thus, as the colonists treasured their heritage, it should not seem surprising that when British soldiers were used to suppress civil disorders in the American colonies it appeared to the Americans that King George was making claim to the same prerogative powers the Tudors and Stuarts had abused. When clashes between troops and disaffected colonists resulted in casualties among the civilians, colonists could claim the authority of Coke and Hale as well as Blackstone to decry those deaths as murders. ${ }^{39}$ When the Administration of Justice Act $^{40}$ was applied to prevent local colonial trials of the British soldiers involved in such incidents, the Second Continental Congress enumerated among the causes for taking up arms that

38. 1 Geo. 1, stat. 2, ch. 14 (1714), revived and continued, 9 Geo. 1, ch. 8 (1722) and 7 Geo. 2, ch. 23 (1734). The latter specifically provided that the lieutenants should have no greater powers than they had under the Restoration statutes of 13,14 , and 15 Charles II, 7 Geo. 2 , ch. $23, \S 3$ (1734).

Only much later did the notion emerge that militia, and even regular troops, could be used "not as soldiers, but as citizens," to constitute the posse comitatus for suppression of riot as distinguished from rebellion; see infra text accompanying notes 73-76. When historians telescope decades into a few sentences, important stages of development can be obscured.

Furthermore, the legal historian must often distinguish between what was conceived to be lawful and what was sometimes nonetheless done. In later years, riots and disorders short of insurrection or rebellion in various parts of the far-flung British Empire were indeed suppressed with military force; but in such instances it became the practice for Parliament to enact acts of indemnity to immunize the troops. The rise of this practice but confirms the point: just as the suppressors of the Peasants' Revolt had required the King's pardon, see supra text accompanying note 29 , so these soldiers required immunizing legislation, precisely because their military suppression of such disorders was "without due process of law."

39. "[I]f a lieutenant, or other, that hath commission of martial authority, doth in time of peace hang or otherwise execute any man by colour of martial law, this is murder; for it is against magna carta cap. 29 [sic]." I W. BlAckstone, Commentaries on the Laws of England 400 (1765) (quoting E. Coke, Third Institute 52 (1644)). See also M. Hale, The History of the Common Law of England 39-40 (2d ed. 1716).

40. 14 Geo. 3 , ch. 39 (1774). 
Act's "exempting the 'murderers' of colonists from legal trial, and in effect, from punishment." In their Declaration of Independence, the Americans pronounced King and Parliament to be lawless tyrants not only "for quartering large bodies of armed troops among us," but also "for protecting them by a mock Trial, from Punishment for any Murders which they should commit on the Inhabitants of these States."42 By intruding with military troops instead of relying upon civilian officials and procedures to deal with domestic disorders, the Declaration of Independence maintained, the King had "affected to render the military independent of and superior to the Civil Power." 4 The Americans saw King George as King Charles, and themselves as asserting (less obsequiously than the 1628 Parliament) the law of the Petition of Right, repudiating the latter-day revival of Tudor-Stuart "martial law" prerogative, and vindicating the established "law of the land." Their insistence through amendment to their new Constitution that the national government not impact life, liberty, or property "without due process of law," was conditioned in major part by their fear of domestic use of the national military force they had newly provided for; they would not have it used, as the British army had been, as a means to suppress civil disorder or execute the laws. ${ }^{4}$

41. 2 Journals of the Continental Congress 1774-1789, at 145 (W. Ford ed. 1905).

42. The Declaration of Independence para. 13, 17 (U.S. 1776).

43. Id. at para. 14. To the same effect, but even more explicitly invoking the due process tradition, the preamble to the South Carolina Constitution of 1776 recited that King George had "dispensed with the law of the land, and substituted the law martial in its stead. . . ." S.C. Const. (1776), printed in 2 Poore, The Federal and State Constitutions, Colonial Charters, and Other Organic Laws of the United States 1615, 1616 (2d ed. 1878).

44. In 1861, Chief Justice Taney explicitly declared that the due process clause of the fifth amendment forbids executive recourse to military intervention for law enforcement. On May 25, 1861, John Merryman had been seized by federal troops at his home in Maryland, a state which had not seceded and where federal (as well as state) civilian authority was intact. While he was being held at Fort McHenry for supposed treason, Merryman's counsel presented a petition for writ of habeas corpus to Chief Justice Taney. The writ was issued, but the general to whom it was directed disobeyed. Taney then delivered an opinion which was given extraordinary circulation and excited widespread commentary in the Congress, the cabinet, and the press of both North and South. Taney declared that he was ruling on the case, not merely as Circuit Justice, but as "Chief Justice of the Supreme Court of the United States at Chambers," see Swisher, The Taney Period, 1836-64, in V History of the Supreme Court of the United States 848,849 n.26 (1974), although the report of his opinion erroneously identifies it as an opinion at circuit, Ex parte Merryman, 17 F. Cas. 144 (C.C.D. Md. 1861) (No. 9847). Merryman is ordinarily cited for its holding concerning habeas corpus; but the decision also reaches the due process issue of military law enforcement. In response to the pur- 


\section{This repudiation of military intervention in domestic law}

ported justification that Merryman's military arrest and confinement was pursuant to presidential authority, the Chief Justice declared that the President

[i]s not empowered to arrest any one charged with an offence against the United States, and whom he may, from the evidence before him, believe to be guilty; nor can he authorize any officer, civil or military, to exercise this power, for the fifth article of the amendments to the constitution expressly provides that no person 'Shall be deprived of life, liberty or property, without due process of law'-that is, judicial process.

With such provisions in the constitution, expressed in language too clear to be misunderstood by any one, I can see no ground whatever for supposing that the president, in any emergency, or in any state of things, can authorize ... the arrest of a citizen, except in aid of the judicial power.

$17 \mathrm{~F}$. Cas. at 149. Reinforcing his due process thesis by reference to the English heritage outlined in the text above, Chief Justice Taney continued:

Indeed, the security against imprisonment by executive authority, provided for in the fifth article of the amendments to the constitution, which I have before quoted, is nothing more than a copy of a like provision in the English constitution, which had been firmly established before the declaration of independence.

17 F. Cas. at 150. Stressing that the case, and his opinion, went beyond the habeas corpus issue, Taney continued:

But the documents before me show, that the military authority in this case has gone far beyond the mere suspension of the privilege of the writ of habeas corpus. It has, by force of arms, thrust aside the judicial authorities and officers to whom the constitution has confided the power and duty of interpreting and administering the laws, and substituted a military government in its place, to be administered and executed by military officers.

The constitution provides, as I have before said, that 'no person shall be deprived of life, liberty or property, without due process of law.'

These great and fundamental laws, which Congress itself could not suspend, have been disregarded and suspended . . . by a military order, supported by force of arms. Such is the case now before me, and I can only say that if the authority which the constitution has confided to the judiciary department and judicial officers, may thus, upon any pretext or under any circumstances, be usurped by the military power, at its discretion, the people of the United States are no longer living under a government of laws, but every citizen holds life, liberty and property at the will and pleasure of the army officer in whose military district he may happen to be found.

17 F. Cas. at 152. At this point the Chief Justice dropped a footnote, declaring:

The constitution of the United States is founded upon the principle of government set forth and maintained in the Declaration of Independence. In that memorable instrument the people of the several colonies declared, that one of the causes which 'impelled' them to 'dissolve the political bands' which connected them with the British nation, and justified them in withdrawing their allegiance from the British sovereign, was that 'he (the King) had affected to render the military independent of, and superior to, the civil power.'

17 F. Cas. at 152 n.3. Taney ordered the court clerk to transmit a copy of his opinion to the President. A short time thereafter, Merryman was released to civilian authorities 
enforcement is the bedrock of due process upon which American government was built. Together with a concept which the early American statesmen drew from a doctrine propounded by Lord Chief Justice Mansfield in 1780, after the Revolution but before the Constitution-a doctrine to be examined at length later in this article ${ }^{45}$ - this is the tradition and the legal premise upon which the first Congresses under the United States Constitution acted when they first came to legislate concerning the use of the military in America. That earliest legislation will be examined below, after first taking note of the several grounds of authority that the 1972 Civil Disturbance Regulations claim.

\section{Faulty Foundations, Part One: Purported Statutory Bases of the Civil Disturbance Regulations}

The stated purpose of the new Civil Disturbance Regulations imposed in 1972 and still in force, is to establish policies and furnish guidance for the utilization of federal troops and other Defense Department resources" "[i]n support of civil authorities during civil disturbances" and "[i]n other related instances where military resources may be used to protect life or Federal property or to prevent disruption of Federal functions."

These 1972 Regulations articulate at length their purported

after being indicted for treason by a grand jury; he was then released on bail, and never prosecuted. See Swisher, supra, at 853.

Although Chief Justice Taney died in 1864, before the whole Court had opportunity to address this same issue, his view was clearly confirmed by the decision of the Supreme Court in Ex parte Milligan, 71 U.S. (4 Wall.) 2 (1866), see supra note 5 and accompanying text.

45. See infra text accompanying notes 75-78.

46. "Military resources include military and civilian personnel, facilities, equipment and supplies under the control of a DOD component." 32 C.F.R. $\$ 215.3$ (c). This definition does not encompass state National Guard troops that have not been federalized.

This article does not concern itself with the legal issues pertaining to state use of National Guard resources. Rather, its focus is solely upon the domestic use of national (i.e., federal) military resources.

The National Guard as organized in each constituent state of the Union is a state military force, for practical purposes the modern successor to the earlier state militia. Each member of each state's National Guard is also-but separately in contemplation of law-a member of the "National Guard of the United States," which is a reserve component of the federal armed forces. As such they may be called to active duty, or "federalized," even temporarily, and individually or as units. Federalized National Guardsmen are part of the national armed forces, and like the militia of an earlier day when called up for federal duty, are within the scope of this article.

47. 32 C.F.R. § 215.1 (1982). 
legal bases. ${ }^{48}$ The 1968 Regulations which the new ones replaced articulated some of the same purported bases; ${ }^{49}$ but the bases claimed for the 1972 Regulations are more numerous and far broader, including sweeping claims of inherent executive power. The breadth and significance of these newly asserted prerogative powers will be examined later in this article; the purported statutory bases must be examined first.

The new and current 1972 Civil Disturbance Regulations, like the old 1968 Regulations, rely as authority for the domestic use of troops in certain circumstances upon three federal statutes, originating generations apart but presently codified as 10 U.S.C. sections 331, 332, and $333 .^{48.1}$ These must each be examined in turn.

\section{A. 10 U.S.C. $\S 331$}

Whenever there is an insurrection in any state against its government, the President may, upon the request of its legislature or of its governor if the legislature cannot be convened, call into federal service such of the militia ${ }^{80}$ of the other States, in the number requested by that State, and use such of the armed forces, as he considers necessary to suppress the insurrection.

This statute is derived from section 1 of the very first statute enacted by Congress pertaining to military troops and domestic turmoil, a statute enacted in $1792 .{ }^{\circ 1}$ The 1792 Act was drafted and adopted in lieu of a provision that was stricken from the Senate version of the so-called Militia Bill a few weeks earlier because of vigorous opposition in the House. ${ }^{52}$ The unac-

48. 32 C.F.R. \& 215.4 (1982).

49. 32 C.F.R. \& 187.4 (1971).

49.1. 10 U.S.C. $\$ \S 331-33$ (1976).

50. The modern counterpart of the state's militia is the National Guard, which, when called into federal service, is a part of the national armed forces. See supra note 46.

51. Act of May 2, 1792, ch. 28, 1 Stat. 264. Section 1 of the original statute is set forth infra note 55 . As originally enacted it authorized only the use of federalized state militia; but after the development of standing federal armed forces another enactment in 1807 authorized the President to use "for the same purposes, such part of the land or naval force of the United States, as shall be judged necessary. . . ." Act of March 3, 1807, ch. 39, 2 Stat. 443.

To avoid confusion, this article refers to the 1792 Act, rather than to the act which actually superseded it in 1795 . See infra note 68 .

52. The Militia Bill was Congress's first measure under U.S. Const. art. I, § 8, cl. 16, "[t]o provide for organizing, arming, and disciplining, the Militia. . ." As finally 
ceptable proposal had provided that the President could call out troops "to execute the laws of the Union, suppress insurrections, and repel invasion." The House debate on that proposal"st indicates that there was no apprehensiveness over the use of military force in circumstances so grave as invasion or insurrection, but that the prospect of military force for law enforcement in any lesser exigency was the subject of very serious concern. Section 1 of the Act that was finally adopted a few weeks later omitted any reference to executing the laws of the Union, and instead dealt only with the extreme circumstances in which it was agreed that distinctively military force is warranted: invasion, and insurrection against the government of a state. ${ }^{\mathrm{s}}$ So much of that section as pertained to insurrection as distinguished from invasion is the antecedent of today's 10 U.S.C. section $331 . .^{\text {se }}$

What is contemplated by the term "insurrection" in 10 U.S.C. section 331 is something quite different from riot, tumult, or civil disorder.

enacted, the Bill became the Act of May 8, 1792, ch. 33, 1 Stat. 271.

53. 3 Annals or Cong. 114-15 (1792).

54. Id. at 553-55 (1792). See also Soldiers, Riots, and Revolution, supra note 14, at 44.

55. Be it enacted by the Senate and House of Representatives of the United States of America in Congress assembled, That whenever the United States shall be invaded, or be in imminent danger of invasion from any foreign nation or Indian tribe, it shall be lawful for the President of the United States, to call forth such number of the militia of the state or states most convenient to the place of danger or scene of action, as he may judge necessary to repel such invasion, and to issue his orders for that purpose, to such officer or officers of the militia as he shall think proper; and in case of an insurrection in any state, against the government thereof, it shall be lawful for the President of the United States, on application of the legislature of such state, or of the executive (when the legislature cannot be convened) to call forth such number of the militia of any state or states, as may be applied for, or as he may judge sufficient to suppress such insurrection.

Act of May 2, 1792, ch. 28, \$ 1, 1 Stat. 264. See also supra note 51 and infra note 68. 56. It will be noted that the statute only authorizes the President to call in militia from states other than the requesting state. The National Advisory Commission on Civil Disorders found this to be curious and "apparently unintended." REPORT OP THR National Advisory Commission on Crvil. Disorders 288 (Gov't Print. Office 1968). The Commission could think of no reason why the President's use of the requesting state's own militia should not have been provided for.

If the Commission had been more alert to the history and purpose of the statute, however, it would have been apparent that the draftsmen were not careless, and that it made perfect sense for them to say exactly what they said. It is to be expected that a state faced with an insurrection would employ its own militia as a matter of course, and that federal assistance would be needed only when the state's own militia proved inadequate to the task so that outside help was needed. 
In the case of an actual insurrection, organized political society is in extremis; the situation is tantamount to war. In such circumstances, it is necessary and appropriate for the government to employ force which is distinctively military in character. It was only in such extreme situations-foreign invasion and genuine insurrection-and never in cases of mere riot or civil disorder, that the English tradition which the founding fathers endeavored to preserve permitted the domestic application of distinctively military force:

Elements of this English tradition-Magna Carta, fourteenth century precedents, the Petition of Right, and the English Bill of Rights-have already been mentioned. ${ }^{67}$ English legislation for dealing with riots and disorders short of insurrection had respected this tradition. The first English riot act had been enacted in 1411, and in accordance with the already established tradition, it had provided for suppression of riots only by the posse comitatus under the command of civil officers. ${ }^{58}$ During the Wars of the Roses and under the Tudors, absolutist monarchs did resort to the expedient of putting down civil disturbances with military force; but legal scholars of that period and our own agree that those actions were in violation of the law of the land. ${ }^{69}$ As declared later in the Petition of Right, the practice of dealing with riots by military means was "wholly and directly contrary to the said laws and statutes of this your realm."вo

When England was beset with scattered riots and disturbances in protest of the Hanoverian succesion in 1714, Parliament enacted a new riot act to correct the defects which the developments of three centuries had created in the old. Just like the 1411 statute, however, the 1714 riot act provided for suppressing riots with the posse comitatus under the control and command of the ordinary local civilian officers, and contained not a hint of any authorization for the use of military troops to suppress any civil disorder, however aggravated the circumstances might be. ${ }^{61}$ Writing a few years later, Lord Chief Justice

57. See supra text accompanying notes $28-38$.

58. 13 Hen. 4, ch. 7 (1411).

59. F. Maitland, The Constitutional History of England 266-68 (1908). See Soldiers, Riots, and Revolution, supra note 14, at 9-10.

60. 3 Car. 1, ch. 1, \$ 8 (1629). See supra note 33.

61. 1 Geo. 1, stat. 2, ch. 5 (1714). Provision for military force was made, simultaneously and by way of important contrast, for dealing with insurrections or rebellions; see 
Hale reiterated the rule that military measures cannot be countenanced in domestic civil affairs so long as the institutions of civil law remain operable. ${ }^{62}$ Blackstone, whose great influence upon lawyers in the new American nation is well known, on the eve of American independence had also affirmed the principle that military force could never be used so long as civil courts could function. ${ }^{63}$

The congressional debates on the 1792 bill which became the antecedent of 10 U.S.C. section 331 make it plain that this rule was very much on the minds of that early Congress; ${ }^{; 4}$ and American courts have continued to adhere to the rule. ${ }^{.5}$ Only a handful of "insurrections" within the intended meaning of this statute have been experienced in American history; for example, the Civil War (1861-1865), Shay's Rebellion (1786-1787), the Whiskey Rebellion (1794), the Dorr Rebellion (1842), and the civil war in the Territory of Kansas (1856).

The statute now codified as 10 U.S.C. section 331 was carefully and deliberately crafted by Congress to apply only in such extreme situations, where the civilian legal institutions of states had been routed by outright rebellion. The term "insurrection" was used for this reason, to preserve the traditional legal prohibition against any use of military force in lesser situations. There is no authority under this statute for any use of military resources to deal with mere riots or civil disorders, however severe.

However, it has become common to cite this statute as if it were authority for sending federal troops into requesting states where nothing really resembling insurrection is present, merely to suppress riots or other violations of state laws. ${ }^{68}$ In 1968 , the

supra note 38 and accompanying text.

62. 1 M. Hale, History of the Common Law 34-36 (4th ed. C. Runnington 1792).

63. I W. Blackstone, Commentaries on the laws of England 152 (1765).

64. 3 Annals or Cong. 574-77 (1792). n.319.

65. For a survey of cases, see Soldiers, Riots, and Revolution, supra note 14, at 67 ,

66. For example, after the urban riots experienced in several cities during the summer of 1967, United States Attorney General Ramsey Clark on August 7, 1967, sent a letter to the governors of all of the states, referring to 10 U.S.C. $\S 331$ as authority for the use of federal troops, at state request, in such instances of "serious 'domestic violence' "; the text of the letter is reproduced in Laird v. Tatum, 408 U.S. 1, 3 n.2 (1972).

The origin of this profound statutory misconstruction is to be found in the period during and after the Civil War. Although the following explanation will not be clear to the reader until the historical and legislative developments have been more fully examined in the pages which follow, it seems appropriate to summarize the explanation 
National Advisory Commission on Civil Disorders in its Official Report recommended that 10 U.S.C. section 331 be amended to remove the doubts of legality attending such use of federal troops in the absence of real insurrection. ${ }^{87}$ No such amendment has ever been enacted by Congress; and even if it were, amending the statute could not alter the constitutional prohibition, respect for which led the Congress originally to draft this statute as it did. Nevertheless, 10 U.S.C. section 331 is cited as one purported legal basis for the Civil Disturbance Regulations. The misconception that this statute can be invoked to deal with riots or disorders, as distinguished from insurrections or rebellions, is one of the foundations for military intervention in the United States.

\section{B. 10 U.S.C. $\S 332$}

Whenever the President considers that unlawful obstructions, combinations, or assemblages, or rebellion against the authority of the United States, make it impracticable to enforce the laws of the United States in any State or Territory by the ordinary course of judicial proceedings, he may call into

here. The sharp demarcation between insurrection and mere riot or disorder, drawn by Congress in the 1792 legislation, was blurred by Congress in 1861 when in the heat of wartime passion it radically revised a companion section of the 1792 Act. See infra text accompanying notes 68-98. Ten years later, still enamored of military efficiency, Congress passed a new statute which also ignores the distinction. See infra text accompanying notes 99-130. Neither of those nineteenth century statutes could survive constitutional analysis if the constitutional rule which prompted Congress to draft the $\mathbf{1 7 9 2}$ legislation as it did were applied; but neither has ever been judicially tested. Since those later measures are codified together with the surviving provision of the 1792 Act, it has been easy for lawyers reading the three provisions as they appear in the Code, without any awareness of the history, to assume (wrongly) that the word "insurrection" was used by the 1792 Congress no more precisely than it was in the Radical (and unconstitutional) legislation during and after the Civil War.

Until 1878, it had been possible, under a subtle but important doctrinal distinction, to use federal military personnel in a non-military capacity to control civil disorders. See infra text accompanying notes 72-80. When that was made unlawful in 1878 (see infra text accompanying notes 148-62), instead of concluding that civil disorders as distinguished from real insurrections must be suppressed by civilian forces the executive branch began to interpret the term "insurrection" in the surviving remnent of the 1792 Act so broadly as to include even "petty attempts to resist or evade the laws." 3 DiarY AND LeTTRRs of RUTherpord B. HaYes 492-93 (1929). See also 16 Op. Att'y Gen. 162 (1878); 17 Op. Att'y Gen. 242 (1881); 17 Op. Att'y Gen. 333 (1882); 19 Op. Att'y Gen. 292 (1889); 19 Op. Att'y Gen. 368 (1889).

Thus, the misconstruction of the term "insurrection" in 10 U.S.C. $\S 331$ is one of long standing.

67. Report of the National Advisory Commission on Civil Disorders 288 (Gov't Print. Office 1968). 
Federal service such of the militia of any State, and use such of the armed forces, as he considers necessary to enforce those laws or to suppress the rebellion.

This statute derives from a separate section of the 1792 statute already discussed; but it was profoundly altered by amendment during the era of the Civil War. Section 2 of the 1792 Act provided:

That whenever the laws of the United States shall be opposed, or the execution thereof obstructed, in any state, by combinations too powerful to be suppressed by the ordinary course of judicial proceedings, or by the powers vested in the marshals by [section 9 of] this act, . . . it shall be lawful for the President of the United States to call forth the militia of such state to suppress such combinations, and to cause the [federal] laws to be duly executed. ${ }^{68}$

After the development of standing federal armed forces, an 1807 amendment to this section of the 1792 Act authorized the President to use federal troops as well as state militia in such circumstances. ${ }^{6 \theta}$

In contrast to section 1 of the 1792 Act, from which derives 10 U.S.C. section 331 discussed earlier, this section 2 of the 1792 Act did concern the enforcement of federal law. It will be recalled from that earlier discussion that the unacceptable proposal deleted a few weeks earlier from the Senate version of the socalled Militia Bill had attempted to treat execution of the laws of the Union, suppression of insurrections, and repulsion of invasion all together in the same terms. ${ }^{70}$ When the Congress set its hand to what became the 1792 Act, it dealt with insurrection and invasion in one section, and dealt separately with the execution of federal laws. The reason it did so, however, was far more than a draftsman's whim.

The terms of section 2 of the 1792 Act quite clearly contemplated the use of troops to execute federal laws as a distinc-

68. Act of May 2, 1792, ch. 28, $\$ 2,1$ Stat. 264. The 1792 Act by its terms was limited in duration to three years. The Act which took its place in 1795, while varying a few details of wording, made no material change of substance. Act of Feb. 28, 1795, ch. 36 , § 2, 1 Stat. 424. Because no material changes were introduced, the 1795 Act was essentially a reenactment of the 1792 Act, but not limited in duration. For convenience, therefore, the text of this article refers throughout to "the 1792 Act" even when what is meant, were it stated more precisely, is the 1795 Act which took its place.

69. Act of Mar. 3, 1807, ch. 39, 2 Stat. 443; see supra note 50.

70. See supra text accompanying notes 51-53. 
tively military force, under no civilian officer other than the President as Commander-in-Chief. If this had been all that the section made provision for, however, it would have authorized precisely what nearly six centuries of legal tradition (distilled into the fifth amendment due process guarantee ratified just a year earlier, in 1791) had forbidden: the option of the executive to enforce the laws by military force rather than by civilian measures. The recorded debates make it clear that quite the opposite was intended: the other phrases of section 2 are crucial to its meaning, and also explain why it was necessary to deal with this most sensitive matter of federal law enforcement separately from, and more elaborately than, the situations covered by section 1.

Section 2 authorized the President to use military force to execute laws only when they were opposed or obstructed "by combinations too powerful to be suppressed by the ordinary course of judicial proceedings, or by the powers vested in the marshals by this act. . . " This language was absent from the bill as it was originally introduced. Vigorous debate was aroused by the original language, and several members denounced the original language as much too indulgent of the use of military force. $^{71}$ Their heated denunciations spawned several amendments to the bill. These amendments not only added the abovequoted language to section 2 , but also added a separate section (section 9) regarding the powers of federal marshals. Only by examining this separate added section can the scope of the authority conferred by section 2 be correctly understood.

Section 9 of the 1792 Act declared that federal marshals and their deputies have "the same powers in executing the laws of the United States, as sheriffs and their deputies in the several states have by law in executing the laws of their respective states." "72 If there were no ready explanation for the inclusion of this provision regarding marshals, it would seem anomalous in a statute concerned with the use of military resources. It would also seem superfluous, because the Judiciary Act of 1789 had already given federal marshals "power to command all necessary assistance in the execution of [their] duty."7s There is, however, an explanation which reveals that section 9 of the Act was 
neither anomalous or superfluous, but was of paramount importance, and is indispensable to understanding section 2. This significance of section 9 , however, cannot be perceived by a modern reader unaware of a crucial doctrine first articulated in 1780 by England's Lord Chief Justice Mansfield-a doctrine which became a fundamental premise of American law.

British troops ("Redcoats") had been employed to suppress rioters in London during the highly destructive Lord Gordon Riots in June, 1780. ${ }^{74}$ Afterwards, Lords and Members of Parliament, aware of the English tradition forbidding military force in domestic affairs, debated whether this use of troops had been lawful. Responding to those who denounced it as reminiscent of the so-called "martial law" prerogative employed by the Tudors and Stuarts, Lord Mansfield rose to justify the utilization of the troops.

The Chief Justice justified the use of "Redcoats" by drawing an essential legal distinction between their utilization in a military capacity, as a distinctively military force, and the utilization of those same organized units of troops in a civilian capacity, in the nature of the posse comitatus. He explained:

I presume it is known . . . that every individual, in his private capacity, may lawfully interfere to suppress a riot . . . . Not only is he authorized to interfere for such a purpose, but it is his duty to do so; and, if called upon by a magistrate, he is punishable in case of refusal. What any single individual may lawfully do for the prevention of crime and preservation of the public peace, may be done by any number assembled to perform their duty as good citizens. It is the peculiar business of all constables to apprehend rioters, to endeavor to disperse all unlawful assemblies, and, in case of resistance, to attack, wound, nay, kill those who continue to resist;-taking care not to commit unnecessary violence, or to abuse the power legally vested in them. . . .

The persons who assisted in the suppression of these tumults are to be considered mere private individuals acting as duty required. My Lords, we have not been living under martial law. . . . Supposing a soldier, or any other military person, who acted in the course of the late riots, had exceeded the powers with which he was invested, I have not a single doubt

74. See Soldiers, Riots, and Revolution, supra note 14, at 31-32. For further accounts of the Lord Gordon Riots, see 3 J. Camprell, The Lives of THe ChiEf Justiczs of England 402-21 (3d ed. 1874); Proceedings Against Lord George Gordon, 21 State Trials 485 (1781); Rex v. Kennett, 172 Eng. Rep. 976 (1781). 
that he may be punished, not by a court-martial, but upon an indictment. ...

The King's extraordinary prerogative to proclaim martial law (whatever that may be) is clearly out of the question. . . . The military have been called in-and very wisely called in-not as soldiers, but as citizens. No matter whether their coats be red or brown, they were employed, not to subvert, but to preserve, the laws and constitution which we all prize so highly. ${ }^{75}$

As a result of Henry II's Assize of Arms in the twelfth century, a decree of Henry III and the Statute of Winchester in the thirteenth century, and the emergence of the Court of Constable and Marshal in the fourteenth century, the same citizens who for some purposes were a military force under a special system of discipline and specialized tribunals were also, regardless of that other role, subject to call by the sheriff or other civil officers as the posse comitatus under common law obligation enforced by civilian courts. ${ }^{78}$ Lord Mansfield's Doctrine adapted that ancient duality of character to a more modern day. ${ }^{77}$

75. 21 The Parliamentary History of England 688-98 (W. Cobbett ed. 1814). Mansfield's doctrine was applied in Rex v. Kennett, 172 Eng. Rep. 976, 984 (1781), and again in Rex v. Pinney, 172 Eng. Rep. 962, 967 n.(b) (1832).

76. See Soldiers, Riots, and Revolution, supra note 14, at 2-5.

77. Pye \& Lowell, supra note 14, at 666-67, suggest that the main point of Lord Mansfield's thesis was to justify the use of troops at the instance of the King and under their officer's orders, rather than at the instance and direction of local magistrates, though they note the "ambiguity of his language." On a more careful reading of Mansfield's argument, however, there is no ambiguity. His thesis was that citizens have a duty to interfere to suppress riots or felonies, even if not called upon by a magistrate, although only if disobedient to such a call could their neglect of that duty be punished. Although not called by the local magistrates, who defaulted in their own responsibility (see Rex v. Kennett, 172 Eng. Rep. 976 (1781)), these troops "as citizens" had responded to that duty; that they had been prompted to do so by the King or their military superiors was quite accidental. Mansfield made no suggestion that the troops could have disregarded instructions of the magistrates had the magistrates undertaken to instruct them. The contrary was in fact implied by Mansfield's insistence that they were civilians, not soldiers, and were acting as a posse and not military instruments of the Crown. That, indeed, was the point of Mansfield's observation that any Tudor-Stuart "martial law" prerogative to supersede regular civil authority was "clearly out of the question." 21 THE Parliamentary History of England 698 (W. Cobbett ed. 1814).

It may be that in later years in England Lord Mansfield's doctrine came to be relied upon as authority for royal rather than local employment of troops; but that was not the significance that the Americans gave to his doctrine. To them, Mansfield's point was that soldiers could be used to suppress civil disorder and execute law-by whomever they might be called-only as civilians and never as a military force at all; and ordinarily they would be called upon for such duty by civil officials more responsible than those whose default in the face of the Lord Gordon Riots had made necessary an invocation from the 
By virtue of this Mansfield Doctrine, sheriffs in the states, having the power of sheriffs at common law to use the posse to execute state laws, could call out militiamen in a civilian capacity, even though organized in their militia units, as part of their posse. The purpose of section 9 of the 1792 Act, the congressional debates make quite clear, was to affirm that federal marshals could do the same for purposes of executing federal laws. The Judiciary Act of 1789 had indeed authorized marshals "to command all necessary assistance," but nothing in the 1789 congressional materials had made it clear that this was specifically to include militia units as civilians in accordance with the Mansfield Doctrine. The legislative history of section 9 of the 1792 Act, by contrast, makes it clear that this was precisely what the new provision was intended to do.

In 1792 there were no standing regular federal armed forces, so the immediate impact of section 9 was to make certain that marshals, like sheriffs in the states, could call up state militiamen as their civilian posse to execute the laws. ${ }^{78}$ Within a few years, however, a modest regular standing federal army had become established. Those regular soldiers were then commonly used by the marshals as civilians even though organized in regular army units, in situations of unrest, riot or disorder where it was well understood that their use as a military force would have been impermissible.

Thus it was proper, pursuant to section 9 of the 1792 Act, to use federal troops as a civilian force to suppress riots and otherwise to enforce federal laws, while it was clearly understood that their use in such situations as a military force would be unlawful. ${ }^{79}$ The resulting practice, and its basis in the Mansfield Doc-

Crown.

78. Pye \& Lowell, supra note 14 , at 688 , assert with reference to $\$ 2$ of the 1792 Act, see supra note 68, "[i]f Congress had intended that federal marshals should draft a state militia into federal service as a posse before a state militia could be called into federal service by the President, it presumably would have said so. It did not. . . ." On the contrary, however, Congress did say so, in terms quite sufficiently clear to the minds of 1792; and that is exactly the practice that was thereafter followed for more than sixty years, see infra notes 78-80 and accompanying text. Again, ignoscunt ut ignarent.

79. An equivalent practice was followed in the states. See, e.g., Ela v. Smith, 71 Mass. (5 Gray) 121, 143 (1855).

An Act of Congress, Act of March 3, 1807, ch. 46, 2 Stat. 445, pertaining to the newly acquired and largely unsettled territories outside the boundaries of any state, authorized the President "to direct the marshal, or officer acting as marshal," and "employ such military force as he may judge necessary and proper," to remove squatters from federally owned lands within those unorganized territories. It is important to understand what 


\section{trine, was confirmed by the Attorney General of the United States in an 1854 Opinion, declaring:}

[T] he posse comitatus comprises every person in the district or county above the age of fifteen years, (Watson's sheriff, p. 60), whatever may be their occupation, whether civilians or not; and including the military of all denominations, militia, soldiers, marines, all of whom are alike bound to obey the commands of a sheriff or marshal. The fact that they are organized

had precipitated this legislation. By presidential address as well as common publications the Congress had been informed of the enterprise of former Vice-President Aaron Burr, collecting a following of Westerners from along the Ohio to settle a large expanse of the newly acquired Louisiana territory, to secede from the Union and establish a government under Burr, and then perhaps to "liberate" Mexico and Texas from Spain. Burr himself had been captured near the end of 1806 , and would be tried for treason in May, 1807; but many of his followers were in the process of establishing themselves in the Louisiana countryside. The regular troops of the Union then numbered some 3,200 men, in addition to a corps of engineers; and most of these were stationed at New Orleans, where some discomforting boundary altercations with the Spanish had occurred. After extensive debate discussing both the Spanish issue and what was denominated as the "insurrection" in the West (meaning Burr's design for secession and sovereignty), see 9 ANNALs op Cong. 332-33, 362-73 (1807), a bill originating in the Senate to almost double the size of the Army was postponed indefinitely in the House. Id. at 681 . That indefinite postponement came the day after the House, after some heated debate, had approved the measure (mentioned above) authorizing military force to oust squatters from federal lands.

The debate on the squatter measure, id. at 664-72, had emphasized the matter of the "insurrection" in Louisiana to such an extent that opponents of the measure criticized it as "a general law, made to suit a particular case," id. at 688; see also id. at 66970. The squatter measure, however, did not mandate military force; it also authorized ouster by "the marshal, or officer acting as marshal." The refusal to enlarge the Army, therefore, meant that with the armed forces concentrated at New Orleans it was only in Louisiana, as a practical matter, that the ouster of squatters might be accomplished by military force; and there, if the information before Congress was correct, the squatters embroiled in the Burr conspiracy were indeed in insurrection against the United States. It is significant that supporters of the squatter measure, for precedent for such authorization of military force, cited the 1794 military suppression of the Whiskey Rebellion, a clear case of insurrection; see id. at 666.

The squatter measure became law the same day as the amendment to the 1792 Act making it lawful for the President to use regular troops as well as militia only to put down insurrections, those assaults upon government authority which civilian measures had proven unable to suppress, see supra note 51. Given the substance of the legislative debates, the refusal to enlarge the Army, and the primacy of concern over the Louisiana situation with the followers of Burr, it would be quite unhistorical to attribute to the 1807 Congress an intent to overthrow the due process tradition and provide for military as an alternative to civilian force even in the absence of insurrection. Even if, under the letter of the squatter measure, military troops might be used elsewhere than in Louisiana, it was only to be in the relatively unsettled territories, where viable civil government had yet to be established; and even then, it was probably not intended to disturb the expectation that the alternative of ouster by "the marshal, or officer acting as marshal," must have priority. 
as military bodies, under the immediate command of their own officers, does not in any wise affect their legal character. They are still the posse comitatus. (xxi Parl. Hist., p. 672, 688, per Lord Mansfield.) ${ }^{\text {so }}$

It is only in the light of this practice authorized by section 9 of the 1792 Act that the import of section 2 of that same Act can be understood. Section 2 did indeed contemplate the utilization of troops as a distinctively military force; but it allowed this intrusion of military force only in circumstances where the resistance to federal law was "too powerful to be suppressed" by civilian means-including the use of military personnel as a civilian force under the command of federal marshals pursuant to section 9 of the 1792 Act.

Two other provisions added by amendment during debate over the 1792 Act serve to emphasize the interplay between sections 9 and 2, and the extreme circumstances contemplated by the latter. The first of these required that, before troops could be used pursuant to section 2, the incompetence of judicial proceedings and the failure of the marshals acting under section 9 must be "notified to the President of the United States, by an associate justice or the district judge."81 The other, applying alike to circumstances under section 2 and under section 1 (discussed earlier), required that when the President deemed it necessary to use such military force he must "previous thereto, by proclamation, command such insurgents to disperse, and retire peaceably to their respective abodes, within a limited time." was only the President personally who was so empowered, and then only as to "insurgents" who had disabled the judicial process and overpowered the marshals and posse and still refused to disperse.

In other words, section 2 of the 1792 Act, while not utilizing the word "insurrection," contemplated circumstances equivalent

80. 6 Op. Att'y Gen. 466, 473 (1854). Pye \& Lowell, supra note 14, at 689 n.361, suggest that the practice of using troops as a posse might have originated with this "ingenious" Attorney General's Opinion in 1854. An opinion by a subsequent Attorney General, however, 16 Op. Att'y Gen. 162 (1878), quoted infra note 162, affirms the historicity of the practice.

81. Act of May 2, 1792, ch. 28, \& 3, 1 Stat. 264. This clause was deleted when the 1792 Act was repealed and substantially reenacted shortly after the Whiskey Rebellion, Act of Feb. 22, 1795, ch. 36, \& 2, 1 Stat. 424. See supra note 68.

82. Act of May 2, 1792, ch. 28, \& 3, 1 Stat. 264 (emphasis added). This provision was included again in the 1795 Act, Act of February 22, 1795, ch. 36, $\S 3,1$ Stat. 424; see supra note 68. It survives as 10 U.S.C. $\$ 334$ (1976). 
to those contemplated by section 1 but involving assaults upon federal rather than upon state authority: rebellions specifically against established civil authority, disrupting "the ordinary course of judicial proceedings," even by exhausting their resources (including troops employed under the Mansfield Doctrine as a civilian posse), could not suppress.

So understood, section 2 of the 1792 Act, in authorizing distinctively military force, was quite consistent with the rule, adopted from the English tradition and newly constitutionalized in the fifth amendment guaranty of civilian due process, which prohibited the use of distinctively military force against civilians except when civil government was under such assault that civilian institutions were incapacitated.

By the time of the Civil War, however, demands for open military action to settle great national issues had caused politicians as well as the public to become impatient with such subtle distinctions as that on which the Mansfield Doctrine relied. The previously familiar difference between "civilian" and "military" utilization of soldiers was no longer perceived. President Buchanan in 1860 used a confused misapprehension of the traditional practice as his excuse for refusing to send federal troops to suppress the spreading insurrection in the South. Referring to the practice of using troops as a posse to assist federal civilian officials, he asserted that it was of no avail because the federal civilian officials had been driven out of the dissident states. ${ }^{84}$ Actually, of course, Buchanan was faced with a clear case of insurrection against the national government, to deal with which avowedly military force was plainly authorized, and to which the civilian posse use of troops had no proper application.

When Lincoln became President, he promptly discarded Buchanan's inhibitions; but he did more than send the army and navy against the insurgents in the South. Lincoln also undertook various distinctively military measures against civilians in the loyal states. Soldiers proceeded throughout the North to arrest persons suspected of disloyalty or espionage, confining many without trial in military prisons for indefinite terms. Mobs pro-

83. This phrase from the Act of May 2, 1792, ch. 28, $\$ 2,1$ Stat. 264, corresponds to the traditional criterion of "insurrection": closure of civil courts. See supra note 63 and accompanying text.

84. 5 J. Richardson, A Compllation of the Messages and Papers of the PresiDBNTS 634 (1897). 
testing the draft or the arrests of deserters were suppressed by troops. Lincoln decreed that draft resisters and persons "affording aid and comfort to rebels" were to be subject to martial law and tried by courts martial. More than 13,000 persons were arrested and confined by military authority in the North. Lincoln's Attorney General, Edward Bates, in a remarkable opinion delivered to the President within four months of his inauguration, had provided the rationale on which these outrages were defended. ${ }^{\mathrm{ss}}$ Bates's opinion asserted that the President had inherent power "to use the army to aid him in the performance of" his duty "to take care that the laws be faithfully executed." Although he asserted that this power was inherent and that the doctrine of separation of powers placed it beyond judicial or legislative restraint, Bates viewed the statutes derived from the 1792 Act as recognizing and aiding it. ${ }^{87}$ The distinction between the use of troops as civilians and their use as a military force was either forgotten or ignored; although Bates paid lip service to the requirement that the military be subordinate to the civil power, he regarded it as sufficient compliance with that precept that the President as Commander-in-Chief "is a civil magistrate, not a military chief."Bs

It was this thesis of Bates, upon which Lincoln had acted, that was denounced and repudiated not only in Ex parte Milligan $^{89}$ but also in other cases, by both federal and state courts. ${ }^{90}$ Those judicial declamations, however, came only later, in the slow course of litigation. To Congress, then composed only of Northern representatives, fevered by the internecine war with the South, and looking to the Union Army for the very survival of the nation as well as the triumph of a great moral cause, it was not a time for respecting such constraints. While Congress would not endorse a presidential power to flout congressional directives, the Congress by legislation would grant vast latitude to this trusted executive. One of the measures enacted during those frenzied first few months of Civil War-within four weeks

85. 10 Op. Att'y Gen. 74 (1861).

86. Id. at 79.

87. Id. at 80,83 .

88. Id. at 79.

89. 71 U.S. (4 Wall.) 2 (1866); see supra text accompanying notes 3-6.

90. E.g., Johnson v. Jones, 44 Ill. 142, 160-61 (1867); Griffin v. Wilcox, 21 Ind. 370, 388-89 (1863). See also In re Egan, 8 F. Cas. 367 (C.C.N.D.N.Y. 1866) (No. 4,303); Milligan v. Hovey, 17 F. Cas. 380, 381 (C.C.D. Ind. 1871) (No. 9,605). 
after the date of Attorney General Bates's radical opinion, and like that opinion blending confused misapprehension of established legal doctrine with extreme determination to eliminate opposition and enforce the national will by any expedient means-was a revision of section 2 of the 1792 Act, concerning use of the military to enforce federal law.

What survives today as 10 U.S.C. section 332 is the substance of that 1861 revision of the language that had been so carefully crafted in $\mathbf{1 7 9 2}$ to preserve the constitutional standard. As the changes wrought by this 1861 Act $^{91}$ are considered, it should be borne in mind that this Act (which survives as 10 U.S.C. section 332) has never been subjected to judicial scrutiny.

The 1861 Act eliminated the requirement of the prior legislation that, before distinctively military force could be employed, the powers vested in federal marshals must first be shown insufficient.92 It was this requirement, premised upon the Mansfield Doctrine, that had contemplated a civilian force of military personnel employed as a marshal's posse, ${ }^{93}$ and limited distinctively military measures to situations when that civilian federal force was overpowered. To the minds of a Congress at war, however, soldiers were soldiers, and nothing else. The subtlety of the Mansfield Doctrine was beyond their understanding. They therefore eliminated from the statute what theretofore had been a crucial element of its constitutional validity, and a safeguard of the civilian due process tradition.

Moreover, whereas the prior legislation had allowed recourse to military force only to deal with "combinations too powerful to be suppressed" by judicial proceedings and the marshals with their posse, ${ }^{94}$ the 1861 Act invited such recourse "whenever . . . it shall become impracticable, in the judgment of the President," to rely upon the ordinary course of judicial

91. Act of July 29,1861 , ch. 25,12 Stat. 281.

92. Act of July 29, 1861, ch. 25, $\S 1,12$ Stat. 281. Cf. Act of May 2, 1792, ch. 28, $\$ 2$, 1 Stat. 264; Act of Feb. 28, 1795, ch. 36, \& 2, 1 Stat. 424.

93. The 1861 Act did contain, as $\S 7$, a provision equivalent to $\S 9$ of the Act of May 2,1792 , ch. 28, 1 Stat. 264, providing that marshals should have the same powers as sheriffs in executing the laws. However, by eliminating the requirement that the resources of the marshal be exhausted prior to use of the military as such, the 1861 Act reduced this provision (originally designed to affirm the posse comitatus use of military personnel by marshals) to a superfluous redundancy; see supra text accompanying notes 72-83. Section 9 of the 1792 Act had been crucial and integral to the scheme of that statute; but $\$ 7$ of the 1861 Act had no significance because the scheme of the statute had been radically changed, and it survived like a useless appendix.

94. See supra text accompanying notes $68-71$. 
proceedings to enforce federal laws.95 Instead of necessity, the statutory criterion for military intervention had now become convenience. With the traditional posse use of troops as civilians forgotten, and no other federal civilian force of significant manpower available, "impracticability" or convenience as a criterion virtually assured that there would now be military intervention in situations where it would not have been allowable before. ${ }^{.6}$

The new Civil Disturbance Regulations rely upon 10 U.S.C. section 332, essentially unchanged since the 1861 Act, as one authority for the measures of military intervention they contemplate. ${ }^{87}$ This statute could not survive judicial scrutiny under the Constitution if established principles of historic due process were applied. The statute has escaped invalidation only because there has never been occasion for it to be judicially reviewed. Without any constitutional footing, it remains as another foundation for military intervention in the United States. ${ }^{88}$

\section{10 U.S.C. $\S 333$}

The President, by using the militia or the armed forces, or both, or by any other means, shall take such measures as he considers necessary to suppress, in a State, any insurrection, domestic violence, unlawful combination, or conspiracy, if it-

(1) so hinders the execution of the laws of that state,

95. Act of July 29, 1861, ch. 25, § 1, 12 Stat. 281.

96. The Act of July 29, 1861, ch. $25, \S 2,12$ Stat. 282 , retained the requirement of a presidential proclamation, and as in the 1792 Act the proclamation was to be one commanding "such insurgents" to disperse; but given the radical changes in the scope of circumstances to which the Act could be applied after 1861 it was no longer possible to treat this antecedent of 10 U.S.C. $\$ 332$ as contemplating only such events as would have been regarded as "insurrections" by the draftsmen of 1792 . Instead of being limited to "combinations too powerful to be suppressed" by civilian means, the scope of the statute now included "assemblages of persons" by reason of which the President thought it "impracticable" to rely upon civilian means. In marked contrast to the rule insisted upon, for constitutional reasons, by the 1792 draftsmen, it now had been provided that the military could be used as an option even in mere riots or disorders which involved none of the traditional indicia of insurrection-armed assault on the institutions of government, rendering civil institutions inoperative.

By retaining the reference to "insurgents" in the proclamation section while so radically expanding the scope of circumstances covered, the 1861 Act contributed to the broadened and fundamentally mistaken interpretation of the word "insurrection" that is used even in 10 U.S.C. $\$ 331$, and thus helped to foster the notion that $\$ 331$ is available for dealing with mere riots; see supra note 66.

97. 32 C.F.R. § 215.4(c)(2)(i)(B) (1981). So also do the 1968 Regulations, see 32 C.F.R. $\S 187.4(c)(2)(1971)$.

98. It is well within the power of Congress to provide for a civilian force either to execute federal laws or to suppress violence at the request of states; see infra note 163. 
and of the United States within the State, that any part or class of its people is deprived of a right, privilege, immunity, or protection named in the Constitution and secured by law, and the constituted authorities of that State are unable, fail, or refuse to protect that right, privilege, or immunity, or to give that protection; or

(2) opposes or obstructs the execution of the laws of the United States or impedes the course of justice under those laws.

In any situation covered by clause (1), the State shall be considered to have denied the equal protection of the laws secured by the Constitution.

This statute originated with the efforts of Reconstruction Era Radicals to suppress at all costs the die-hard Southern resistance to the social consequences of the Civil War. It was originally enacted as section 3 of the Ku Klux Klan Act of $1871 .^{89}$ The sequence of the several clauses, and in some relatively insignificant respects the substance, have been modified since 1871; but the essential content of what is now codified as 10 U.S.C. section 333 has remained unchanged. For comparison, the language of the 1871 Act is set out in the footnote below. ${ }^{100}$

It is important to place this 1871 enactment in historical context. The Civil War had ended in April, 1865. In some vanquished confederate states even before the end of the war, and

99. Act of April 20, 1871, ch. 22, § 3, 17 Stat. 13, 14 .

100. That in all cases where insurrection, domestic violence, unlawful combinations, or conspiracies in any State shall so obstruct or hinder the execution of the laws thereof, and of the United States, so as to deprive any portion or class of the people of such State of any of the rights, privileges, or immunities, or protection, named in the Constitution and secured by this act, and the constituted authorities of such State shall either be unable to protect, or shall, from any cause, fail in or refuse protection of the people in such rights, such facts shall be deemed a denial by such State of the equal protection of the laws to which they are entitled under the Constitution of the United States; and in all such cases, or whenever any such insurrection, violence, unlawful combination, or conspiracy shall oppose or obstruct the laws of the United States or the due execution thereof, or impede or obstruct the due course of justice under the same, it shall be lawful for the President, and it shall be his duty to take measures, by the employment of the militia or the land and naval forces of the United States, or either, or by other means, as he may deem necessary for the suppression of such insurrection, domestic violence, or combinations; and any person who shall be arrested under the provisions of this and the preceding section shall be delivered to the marshal of the proper district, to be dealt with according to law.

Act of April 20, 1871, ch. 22, § 3, 17 Stat. 13, 14. 
in all such states except Texas within six months after, new civilian governments under new or amended state constitutions had been elected and installed. There were Radicals in Congress, however, who opposed the presidential plan of reconstruction under which these post-war civilian governments had been established. By the end of 1865 , these Radicals had become the dominant force.

None of the new governments in the formerly secessionist states had granted blacks the right to vote, and all but Tennessee had enacted statutes quite discriminatory against blacks. Outrage at what Northerners regarded as an unrepentant attitude on the part of Southern whites, together with concern for assuring Republican dominance in national politics, brought more and more members of Congress into the Radical camp.

The Radicals were not yet ready to put aside the distinctively military means with which the war itself had been won. In February, 1866, Congress passed a bill to enlarge the scope of the Freedmen's Bureau, which had been created within the War Department a year before. The bill provided that any person in the former secessionist states accused of infringing the rights of a former slave would be triable by a military tribunal, or an agent of the Freedmen's Bureau in accordance with martial law. President Johnson, however, vetoed that flagrantly unconstitutional measure. ${ }^{101}$ A second Freedmen's Bureau bill, somewhat more moderate but still providing for military protection and military jurisdiction regarding freedmen's rights, was enacted over Johnson's veto four months later. ${ }^{102}$

In the meantime, in April Congress had enacted (also over a presidential veto) the Civil Rights Act of $1866 .^{103}$ That beneficent legislation was marred by two provisions which countenanced military action to enforce its terms. The first authorized process servers appointed pursuant to the Act to "summon and call to their aid" not only the posse comitatus, but also "such portion of the land or naval forces of the United States, or of the militia, as may be necessary to the performance of the duty with which they are charged, and to insure a faithful observance of the clause of the Constitution which prohibits slavery. . .."104

101. President Johnson's veto message appears at Cong. GLoBe, 39th Cong., 1st Sess. 915-17 (1866).

102. Act of July 16, 1866, ch. 200, 14 Stat. 173.

103. Act of April 9, 1866, ch. 31, 14 Stat. 27.

104. Id. at $\S 5$. 
The second provided:

That it shall be lawful for the President of the United States, or such person as he may empower for that purpose, to employ such part of the land or naval forces of the United States, or of the militia, as shall be necessary to prevent the violation and enforce the due execution of this act. ${ }^{105}$

These distinctively military measures were authorized by Congress even though federal civilian authority was fully established at that time in all of the formerly secessionist states. There were indeed incidents of violence and intimidation against black citizens, which certainly warranted federal intervention; but there was nowhere any such assault upon civilian institutions as would have justified that intervention being military in character.

The text of what two years later would be ratified as the fourteenth amendment to the Constitution was approved by Congress in mid-1866; but the legislatures of ten of the Southern states refused to ratify it. Incensed at this rejection by the southern post-war civil governments, the Radicals in Congress now determined upon their most sweeping militaristic moves. They enacted the Military Reconstruction Act in March, 1867, ${ }^{100}$ on the articulated premise that no legal civilian governments existed in those states. That Act established five military districts comprehending the ten states in question, each to be governed under martial law by a commanding army general with an ample force of troops. The Act gave these military commanders discretion whether to try offenders in military tribunals or to allow trials by the established local civilian courts. Even on the dubious premise that no civilian state governments existed, there was no basis for denying that civilian federal authority had been reestablished in those states since the war had ended almost two years before. There was no colorable constitutional justification, therefore, for making the reconstruction presence of the federal government military in form.

The Military Reconstruction Act was passed over President Johnson's veto; and having doubts therefore about the President's will to execute it, Congress ordained that all orders regarding military operations, even if issued by the President, were void unless issued through the "general of the army," 
whom they ordained could not be removed or relieved of command without Senate approval. ${ }^{107}$ "General of the Army" was a rank which Congress had authorized seven months earlier for a sole incumbent to be appointed with advice and consent of the Senate, "to command the armies of the United States."108 General Ulysses S. Grant had been appointed. The earlier Act had provided that the General of the Army should serve "under the direction and during the pleasure of the President;" by the later provision immunizing him from presidential removal and requiring all orders regarding military operations to be issued through him, however, Congress effectively placed General Grant rather than the President in control of reconstruction.

Under Grant's command the military district commanders ousted thousands of local civilian officials and six state governors, appointing others in their places. State legislation was set aside or modified by military decrees. The army purged the legislatures of at least three states. A distinctively military force of some 20,000 soldiers was the primary peacekeeping force, aided by militia of blacks organized by the federal military commanders after Congress had declared the states' own militias disbanded. ${ }^{109}$ Any doubts as to whether such military overthrow of civilian governments was within Congress's intention were eliminated four months later when Congress amended the original Reconstruction Act to ratify and explicitly authorize what had been done, ${ }^{110}$ and to further provide that "no district commander ... or any of the officers or appointees acting under them, shall be bound in his action by any opinion of any civil officer of the United States."

No one expected that such blatant intrusions of military force into civil affairs, such suspension of civilian authority by military authority, could be upheld as constitutional by any civil court. General Grant himself said of the Reconstruction legislation: "Much of it, no doubt, was unconstitutional; but it was hoped that the laws enacted would serve their purpose before the question of constitutionality could be submitted to the judiciary and a decision obtained." 112

107. Act of March 2, 1867, ch. 170, § 2, 14 Stat. 486-87.

108. Act of July 25, 1866, ch. 232, 14 Stat. 223.

109. Act of March 2, 1867, ch. 170, § 6, 14 Stat. 487.

110. Act of July 19, 1867, ch. $30, \S \S 2,4,15$ Stat. $14,15$.

111. Id. at $\$ 10,15$ Stat. at 16 .

112. Quoted in Morison, Commager \& Leuchtenburg, A Concise History of the 
Indeed, the Military Reconstruction Act had been enacted only four months after the Supreme Court, in Ex parte Milligan, a case arising out of actions taken in a Northern state during the war itself, had vigorously reaffirmed the established constitutional rule. The Court had said:

If, in foreign invasion or civil war, the courts are actually closed, and it is impossible to administer criminal justice according to law, then, on the theater of active military operations, where war really prevails, there is a necessity to furnish a substitute for the civil authority, thus overthrown, to preserve the safety of the army and society; and as no power is left but the military, it is allowed to govern by martial rule until the laws can have their free course. As necessity creates the Rule, so it limits its duration; for, if this government is continued after the courts are reinstated, it is a gross usurpation of power. Martial rule can never exist where the courts are open, and in the proper and unobstructed exercise of their jurisdiction. It is also confined to the locality of actual war. ${ }^{118}$

At least one lower federal court had held that where a post-war civilian government had been established (in South Carolina) a civilian could not be tried for a crime by court martial.114 To prevent further embarrassment by judicial opinions denouncing the obviously illegal measures the Radicals were determined to pursue, Congress ordained that "no civil court of the United States, or of any state, or of the District of Columbia, or of any district or territory of the United States, shall have or take jurisdiction of" any case arising out of military actions taken between the date of President Lincoln's inauguration and July 1, 1866, a date fifteen months after the end of the war. ${ }^{115}$

American Republic 344 (1977).

113. Ex parte Milligan, 71 U.S. (4 Wall.) 2, 127 (1866).

114. In re Egan, 8 F. Cas. 367 (C.C.N.D.N.Y. 1866) (No. 4,303).

115. Act of March 2, 1867, ch. 155, 14 Stat. 432. The constitutionality of this brazen attempt to foreclose all judicial inquiry was more than a little dubious. The Act was ignored by the circuit courts, and did not prevent relief in damages for Lambdin Milligan against the military personnel who had unconstitutionally (see supra note 113) confined him; Milligan v. Hovey, 17 F. Cas. 380 (C.C.D. Ind. 1871) (No. 9,605). The Supreme Court never faced the necessity of ruling on the validity of this purported jurisdictional foreclosure. The only occasion when it was invited to do 80 was in Beckwith v. Bean, 98 U.S. 266 (1878), where the circuit court's disregard of the 1867 jurisdiction divesting statute was one of the points of purported error relied upon by the Attorney General in seeking reversal of a damage judgment rendered by the circuit court for a wartime arrest in Vermont. The majority of the Supreme Court found that a different error, equally relied upon, necessitated reversal, and noted, "We express no opinion as to the construc- 
In shameless defiance of constitutional law, military reconstruction proceeded apace. Twice in the first months after the process began, states sought to have the 1867 legislation invalidated by the Supreme Court; but their requests for injunctions against executive action to preserve rights of sovereignty were beyond the constitutional jurisdiction of the Supreme Court. ${ }^{116}$ A proper case putting in issue the constitutionality of the Military Reconstruction Act soon arose, however, when a person held prisoner by the military district commander in Mississippi sought release by writ of habeas corpus. When the Supreme Court, in February 1868, refused to dismiss the prisoner's appeal $^{117}$ and proceeded to hear arguments on the merits, Congress, over President Johnson's veto, forthwith repealed the particular jurisdictional statute upon which the Court's jurisdiction of that appeal was based. ${ }^{118}$ That occasion for judicial invalidation of the reconstruction legislation was thus foreclosed. ${ }^{110}$ Other courts did find occasion to denounce acts done by the military in the South during the interval between the end of the war and the commencement of military reconstruction. ${ }^{120}$ The

tion of those statutes [the 1867 jurisdictional foreclosure and another], or as to the questions of constitutional law which may arise thereunder." 98 U.S. at 285. Significantly, however, the Court's order in Beckwith was for a new trial, whereas application of the 1867 statute would have dictated dismissal of the case for lack of subject matter jurisdiction rather than remand for a new trial. Justices Field and Clifford, dissenting from the majority's view on the different issue addressed, and thus reaching the constitutional issue which the majority purported to reserve, set forth compelling arguments to show that the 1867 Act's attempted jurisdictional foreclosure was unconstitutional. 98 U.S. at 285-306. Majority opinions in other cases from the same period suggest strongly that the other Justices, had they chosen to address the issue in Beckwith, would have agreed; e.g., Raymond v. Thomas, 91 U.S. 712 (1876), discussed infra note 121.

Earlier acts passed by Congress in 1863 and 1866, not addressing jurisdiction but granting immunity to soldiers and others who had acted pursuant to orders of the President or his military commanders, were held unconstitutional and ignored by state courts, in Johnson v. Jones, 44 Ill. 142 (1867), and Griffin v. Wilcox, 21 Ind. 370 (1863). The Supreme Court noted but found it unnecessary to rule on the same issue in Mayor of Nashville v. Cooper, 73 U.S. (6 Wall.) 851 (1868); and subsequent consideration of the dubious features of the 1863 and 1866 statutes was foreclosed by the valid two year statute of limitations imposed for such claims; see Mitchell v. Clark, 110 U.S. 633 (1844).

116. Georgia v. Stanton, 73 U.S. (6 Wall.) 50 (1867); Mississippi v. Johnson, 71 U.S. (4 Wall.) 475 (1867).

117. Ex parte McCardle, 73 U.S. (6 Wall.) 318 (1868).

118. Act of March 27, 1868, $\$ 2,15$ Stat. 44. The jurisdictional foreclosure statute enacted in 1867, see supra note 114, did not apply because the facts in McCardle had arisen after July 1,1866 , the cutoff date of that statute.

119. Ex parte McCardle, 74 U.S. (7 Wall.) 506 (1869).

120. E.g., McLaughlin v. Green, 50 Miss. 453, 461 (1874); In re Egan, 8 F. Cas. 368 (C.C.D.N.Y. 1866) (No. 4,303). 
Supreme Court was never squarely faced with the issue, however, although its disposition of related issues during the next several years makes it clear that it would have denounced the legislation had a proper case within its jurisdiction been made. ${ }^{121}$ By the summer of 1868 , reconstructed civil governments had been set up in eight of the former secessionist states, and the army withdrawn. Reconstruction in the others was completed in 1870. By then, the general who had been in charge of the whole enterprise had become President of the United States.

The end of the military reconstruction program did not mark the end of the Radicals' infatuation with military force as the means to impose the national will upon the South. Violence and intimidation against blacks had not been ended by the process of reconstruction; in fact, Southern blacks bore the brunt of Southern extremist retaliation for the outrageous military measures the Radicals had employed on their behalf. Continued violence provoked new responses from Congress; and while martial law as such was not reimposed, Congress again indulged the Radicals' penchant for enforcement of the laws with military force. The so-called Enforcement Act of $1870,{ }^{122}$ like the Civil Rights Act passed four years before, ${ }^{128}$ empowered process servers appointed for its purposes to call out not only the posse, but portions of the army and navy, ${ }^{124}$ and also authorized the President to employ the armed forces to aid in the execution of that

121. See, e.g., Beckwith v. Bean, 98 U.S. 266 (1878). In Raymond v. Thomas, 91 U.S. 712 (1876), the Supreme Court considered an order of a Reconstruction military commander, purportedly authorized by the Military Reconstruction Acts, which annulled a decree issued by a civilian chancery court during the Reconstruction period. Although the commander's order was within the letter of the authorizing Reconstruction Acts, the Court held it void-but without undertaking to declare the Acts themselves void. The Court said:

The meaning of the legislature constitutes the law. A thing may be within the letter of a statute, but not within its meaning. . . .

The clearest language would be necessary to satisfy us that Congress intended that the power given by these Acts should be so exercised.

It was an arbitrary stretch of authority, needful to no good end that can be imagined. Whether Congress could have conferred the power to do such an act, is a question we are not called upon to consider. It is an unbending rule of law, that the exercise of military power, where the rights of the citizen are concerned, shall never be pushed beyond what the exigency requires.

91 U.S. at 71.

122. Act of May 31, 1870, ch. 114, 16 Stat. 140, repealed by Act of Feb. 8, 1894, ch. 25, 28 Stat. 36.

123. See supra text accompanying notes 104-05.

124. Act of May 31, 1870, ch. 114, $\S 10,16$ Stat. at 140, 142, repealed by Act of Feb. 8, 1894, ch. 25, 28 Stat. 36. 
Act. ${ }^{125}$

This same mad attachment to the expedient of military means for law enforcement, despite repeated judicial pronouncements exposing its constitutional invalidity, accounts for the military enforcement provision of the $1871 \mathrm{Ku}$ Klux Klan Act, which survives as 10 U.S.C. section 333 . The 1871 Act made no distinction between "insurrection" and mere "violence, unlawful combination, or conspiracy;" for any of these circumstances it authorized distinctively military force:

[I]n all such cases, . . . it shall be lawful for the President, and it shall be his duty to take such measures, by the employment of the militia or the land and naval forces of the United States, or of either, or by other means, as he may deem necessary for the suppression of such insurrection, domestic violence, or combinations. . . . .

Moreover, this 1871 Act contained no requirement that civilian means of federal law enforcement be first exhausted. The Act was confined to circumstances in which state authorities "shall either be unable to protect, or shall, from any cause, fail in or refuse protection of the people in [their federal constitutional] rights ... ";127 but there was no requirement that a civilian federal force, such as the federal marshals and posse, be considered or employed before resort to distinctively military force.

In other words, this 1871 Act displayed the very features that had so alarmed most members of the Congress in 1792. At that earlier time, when the members of the Congress were loyal to the traditional and constitutional due process restraints on the domestic application of military force, they had tailored their legislation to conform to the constitutional requirements. ${ }^{128}$ Among the post-Civil War Radicals, however, there was no such respect for the civilian constitutional tradition; and the 1871 Act was adopted despite its patent offense to constitutional law.

While most of the other Reconstruction Era statutory provisions calling for military intervention one by one have passed away, ${ }^{128}$ this one still remains, a relic of that shameful period

125. Id. at $\S 13,16$ Stat. at 143.

126. Act of April 20, 1871, ch. $22, \S 3,17$ Stat. 13, 14.

127. Id.

128. See supra text accompanying notes 68-78.

129. The substance of section 5 of the Civil Rights Act of 1866, see supra note 104, allowing appointment of military personnel to assist in executing warrants or other process in connection with certain civil rights offenses, still survives as 42 U.S.C. 1989 
when the Congress and a General-turned-President knowingly and willfully determined to trample constitutional principle underfoot in their march on an otherwise noble crusade. The statute has occasionally been invoked by presidents as a pretext for the intervention of distinctively military force, as in the Pullman strike of 1894 and the racial and urban riots of the 1960's; but never in those instances or in any other has any court had occasion to consider its constitutional validity. ${ }^{130}$ It seems quite impossible that it could survive judicial scrutiny. Nevertheless, generations after the other excesses of the Reconstruction Era have been forgotten, this one bastard offspring of the rapacious militarism of that day remains, to serve as a third foundation for military intervention in the United States.

\section{Faulty Foundations, Part Two: Other Purported Bases of the Civil. Disturbance Regulations}

The three statutes examined in the preceding part of this article had been claimed as authority for the 1968 Civil Disturbance Regulations and are likewise claimed by the new Regulations which have been in force since 1972 . Unlike the 1968 Regulations, however, the 1972 Regulations also claim to be authorized on three additional grounds.

The first of these claimed additional bases is a sweeping concept of inherent executive emergency power. The second is a purported constitutional power of the executive to use military force to protect federal property and federal governmental functions. The third is an obscure Joint Resolution of Congress per-

\section{(1976).}

130. In re Debs, 158 U.S. 564 (1895), was a habeas corpus case, reviewing an imprisonment for contempt of an injunction restraining participation in the Pullman strike. No issue concerning the use that had been made of troops, or the validity of the statute here under discussion, was present in the case; the issue was whether a federal court had jurisdiction to issue such an injunction on the complaint of the United States. While holding that it did, the Supreme Court in dicta noted that even if no such effective judicial weapon were available the federal government still would not be impotent: "If the emergency arises, the army of the Nation, and all its militia, are at the service of the nation to compel obedience to its laws." Id. at 582 (emphasis added). Nothing in the case required the Court to consider whether such an "emergency" had arisen in the circumstances before it, and it refrained from doing so. Neither did it attempt to elaborate in general terms what might constitute an "emergency" sufficient to warrant such military means, although the context of its dictum was a discussion of the incapacity of civil courts, reminiscent of the classic test of insurrection by which the legitimacy of recourse to the military had traditionally been determined. See also id. at 597. The Debs case is discussed further infra note 138. 
taining to the Secret Service. Each of these purported bases must be considered in turn-together with a recently reconfirmed century-old statute which destroys all three.

\section{A. The Purported "Emergency Authority," and the Posse Comitatus Act}

The new Civil Disturbance Regulations claim that the Constitution, without the aid of any statute, confers what the Regulations call "the emergency authority." This purportedly authorizes

prompt and vigorous Federal action, including use of military forces, to prevent loss of life or wanton destruction of property and to restore governmental functioning and public order when sudden and unexpected civil disturbances, disasters, or calamities seriously endanger life and property and disrupt normal governmental functions to such an extent that duly constituted local authorities are unable to control the situations. ${ }^{131}$

The Regulations maintain that exertion of this "emergency authority" is appropriate whenever "civil disturbances, disasters, or calamities" endanger life or property (whether or not federal property) or "disrupt normal governmental functions to such an extent that duly constituted local authorities are unable to control the situations." The term "civil disturbances" is given a broad definition for purposes of the new Regulations, to include not only "group acts of violence" but also other "disorders prejudicial to public lâw and order."132 "Disorder," which is not defined in the Regulations, is a term susceptible of many interpretations. So also is the word "calamities," which is not defined in the Regulations. There may be political or economic or social "calamities"--disturbances" of the established political order-that do not involve "group acts of violence" or any of the characteristics commonly connoted by terms such as "riot," "tumult," and "unlawful assembly" at all.

This "emergency authority" may be invoked, according to the new Regulations, whenever a disorder is serious enough to "disrupt normal governmental functions to such an extent that duly constituted local authorities are unable to control the situations." The reference to "duly constituted local authorities" 
makes it evident that the purported power is to be invoked even when normal state or local governmental functions are disrupted, and not merely when federal activities are disrupted. Yet there is no explanation given in the Regulations as to what constitutes "normalcy" of governmental functions, what constitutes their "disruption," or what might constitute "inability" on the part of local authorities to control a situation. It is clear, however, that the Regulations countenance federal military intervention in a state without any request from the state at all, even where the intervention is purportedly for the purpose of enforcing state law; the judgment as to whether local authorities are able to control a situation is to be made, not by local or state governmental officials, but by federal or even by military officials, as provided elsewhere in the Regulations. ${ }^{193}$

Moreover, according to the new Regulations the role that the federal troops are to play in such situations is not a subordinate role of assistance to civil authorities in their own enforcement of the laws. Rather, on the premise that the local civil authorities are "unable to control" the situation, the Regulations give the military a free hand to "restore governmental functioning and public order. . . ."134

All of this would be remarkable enough if the discretion to invoke this purported "emergency authority" were reserved to the President himself; but under the new Regulations, it is not. Each of the statutes in title 10, examined earlier, whatever its limits or constitutional faults, at least requires personal involvement of the President; for each requires the issuance of a presidential proclamation. ${ }^{135}$ The Regulations, however, specifically provide that not even a presidential executive order or presidential directive to the Secretary of Defense is required in cases within this purported "emergency authority."138 The critical decisions all may be made by inferior-and indeed, by military-officials, as will be elaborated more fully later in this article. ${ }^{137}$

The 1968 Regulations had contained nothing at all comparable to this purported "emergency authority." It is the offspring 
of Nixon-era claims to enlarged executive privilege and power. ${ }^{138}$ Although it is described in the Regulations as conferred by the Constitution, one would search that document in vain for any language conferring any such "emergency authority" in express terms. It is not surprising, therefore, that the Regulations do not pretend that the "emergency authority" is conferred by any express language, but rather assert that it is "based upon the inherent legal right of the U.S. government-a sovereign national entity under the Federal Constitution-to insure [sic] the preservation of public order and the carrying out of governmental operations within its territorial limits, by force if necessary."198 Since the Regulations acknowledge that the "emergency authority" has no statutory basis, it is apparent that what is being claimed is that it exists as an inherent prerogative of the executive branch. In fact, as will be seen below, the Regulations maintain that this executive prerogative persists in spite of a statute which specifically negates it.

To discredit this sweeping claim of inherent executive prerogative to employ military force to execute the laws, it is not even necessary to maintain that such a claim is precluded by the

138. While Nixon was Vice President under Eisenhower, Attorney General Brownell had expressed "grave doubts as to the authority of the Congress to limit the [purported] constitutional powers of the President to enforce the laws and preserve the peace under circumstances which he deems appropriate," with military troops. 41 Op. Att'y Gen. 313, 331 (1957). Brownell did not elaborate his "doubts," however, because he claimed congressional authority by virtue of 10 U.S.C. $\$ \$ 332-33$ (1976) for the use of troops in connection with the Little Rock, Arkansas, school integration crisis.

A similar assertion of the unlimitable inherent executive power was made at the end of the nineteenth century by the then Judge Advocate General of the Army: G. LuRBRR, The Use of the ARmy in AID of THE Civil Power (1898). Lieber, however, could offer absolutely no relevant judicial authority for his assertion. One authority which Lieber sought to turn to his purpose was the statement of the Supreme Court in Ex parte Siebold that:

We hold it to be an incontrovertible principle, that the government of the United States may, by means of physical force, exercised through its official agents, execute on every foot of American soil the powers and functions that belong to it. This necessarily involves the power to keep the peace to that extent.

Ex parte Siebold, 100 U.S. 371,395 (1879). Siebold, however, involved the use of federal marshals, not military troops, and nothing the Court said in any way supports the use of military force. Moreover, nothing in Siebold addresses the relative authority of President and Congress, or supports an assertion that the Congress is unable to control the use by the President even of federal marshals, let alone the federal military.

The other claimed authority misapplied by Lieber was a dictum in In re Debs, 158 U.S. 564, 581-82 (1895), already discussed supra note 130. Nothing in the Debs dictum addressed at all the question of Congress's power to control the President's use of troops. 139. 32 C.F.R. \& $215.4(c)(1)(1981)$. 
constitutional rule of civilian due process, which historically developed as a reaction against precisely such claims by successive English kings. Even if one is unpersuaded by the contention advanced in the preceding pages-that the language of due process in the fifth amendment was intended to guarantee the traditional rule against military intrusions at the instance of any branch of the federal government-one must still consider the constitutional doctrine of the separation of powers. When that doctrine is applied, this claim of sweeping inherent executive power confronts a constitutional obstacle which would be insurmountable even if all of the statutory provisions heretofore examined, objectionable though they seem to this writer, were deemed valid.

The President's power and duty to "take Care that the laws be faithfully executed"140 repels any suggestion that he may flout them. To be sure, even without specific statutory authorization the executive may petition the judiciary to exercise its equity powers so as to protect federal interests from harm; ${ }^{141}$ and it is arguable that some direct executive measures might properly be taken to promote or preserve federal interests, even without judicial involvement, where no statute on point may be found. ${ }^{142}$ Presidential power to act in disobedience of a statute, however, could be sustained only on a finding that the statute were void.14s Although the Constitution makes the President Commander-in-Chief of the armed forces, ${ }^{144}$ it just as clearly gives to Congress the power "to make Rules for the Government and Regulation of the land and naval Forces,"145 and to make all laws necessary and proper to effectuate not only the latter but also the President's Commander-in-Chief power. ${ }^{146}$ Statutes restricting the use of the military, therefore, have an ample constitutional base. Thus it is not possible, unless the Constitution be rewritten, to maintain that the President has authority to

140. U.S. Const. art. II, $\S 4$.

141. In re Debs, 158 U.S. 564 (1895).

142. See Youngstown Sheet \& Tube Co. v. Sawyer, 343 U.S. 579 (1952).

143. Id.

144. U.S. Const. art. II, $\S 2$.

145. U.S. Const. art. I, cl. 14; see also cl. 15, 16. To make rules for their government and regulation must mean to make the rules according to which the Commander-inChief is to govern them, and seems clearly to preclude the notion that he may govern or use them contrary to the rules thus laid down by Congress.

146. U.S. Const. art. I, $\S 8$, cl. 18. 
make any use of the armed forces, in domestic situations, ${ }^{147}$ which Congress has specifically forbidden.

Congress acted a century ago to negate precisely the same executive "emergency authority" which the new Regulations now claim. The Radicals' military reconstruction of the former secessionist states had been completed in 1870 . Nevertheless, throughout the presidency of General Grant, federal army troops continued to be used with some frequency to execute federal laws in the South, pursuant to provisions of the Civil Rights Act of $1866,{ }^{148}$ the Enforcement Act of $1870,{ }^{149}$ the Ku Klux Klan Act of 1871,180 and otherwise. By the end of President Grant's second term, this continued recourse to the military expedient was exacting a substantial political toll. As voter sentiment swung away from the Radical Republicans and toward the Democrats, accusations were made in Congress that the federal troops were intimidating voters in the South, seizing political prisoners, interfering with civil governments in the states, and even removing and installing state legislatures again. ${ }^{151}$

In the presidential election of 1876 , Democrat Tilden had won a popular plurality of more than a quarter-million votes, carrying four Northern states as well as nearly all of the South. His vote in the electoral college, however, was one short of a majority so long as four states where returns had been challenged remained in doubt; and in the end, the electoral votes of all four were awarded to Republican Hayes, who thus became President by a margin of one electoral vote. In two of the states where the vote was in question-Louisiana and South Carolina-unpopular Republican governments were being maintained in power only with federal bayonets. While the outcome of the election was still unresolved, Democrats in Congress charged that, had it not been for intimidation of voters by the federal troops, the vote in many districts would have differed enough that an electoral majority for Tilden would have been

147. There is good constitutional authority for the proposition that the President is the paramount instrument of the nation for dealing in international affairs, and this proposition might support a corollary claim to make use of troops in connection with international affairs without regard to congressional directives. We are concerned here, however, with domestic situations, where the corollary falls because the proposition of presidential paramountcy has no place.

148. See supra text accompanying notes 103-05.

149. See supra text accompanying notes $122-25$.

150. See supra text accompanying notes $126-27$.

151. See 7 Cong. Rec. 3849, 3850-52, 4240, 4245, 4248 (1878). 
assured. As a result the House of Representatives, where the Democrats had held a majority since the previous congressional election, passed a Resolution in December 1876, calling upon outgoing President Grant to account for the use that had been made of federal troops in the South during the several months preceding the November election. On January 22, 1877, six weeks before leaving office, Grant sent to the House his reply. ${ }^{152}$

Grant's reply did not assuage the anti-militaristic sentiment of the Democrats in the House, who responded by attaching to the 1877 appropriation bill for the army a substantive rider designed to restrict the domestic use of troops. However, the decision of President Hayes at the commencement of his presidential term to withdraw the army from South Carolina and Louisiana (whereupon the carpetbag Republican governments in those states immediately yielded control to the Democrats) diminished the felt urgency of reform. While the House insisted on its rider, the Senate would not agree; and as a result no army appropriation bill at all was passed until November, when the fiscal year was half over and the House, judging Hayes to be more restrained than Grant in the use of troops, agreed to postpone the reform. ${ }^{153}$ The next year, however, those who were determined to curtail military intervention in civilian affairs did secure approval in both houses for a similar rider to the Army Appropriation Act of June 1878. ${ }^{154}$ The terms of that rider, which came to be called the "Posse Comitatus Act," were directly responsive to the arguments which President Grant had put forward in his reply to the House Resolution a year and a half before.

In his reply Grant had specified several different legal bases upon which he considered the various instances of the use of military troops to have been justified. The situation in South

152. The House Resolution and President Grant's reply are printed in G. LIEBER, The Use of the Army in Aid of the Civil Power 4-9 (1898).

153. During the interval created by this impasse in the last half of 1877 , when the Army was without an appropriation, President Hayes was confronted with widespread labor riots. Despite the urgings of cabinet members, other advisers, and industrial leaders, who wanted to see vigorous strike-breaking action, Hayes exercised considerable restraint in the use of troops, employing them only late in the period of the strike and then only to enforce judicial process. Hayes' relative moderation, compared to Grant's use of troops, doubtless contributed to the willingness of the House to postpone its insistence upon legislative repudiation of Grant's claim of inherent executive power until the following year.

154. Act of June 18, 1878, ch. 263, $\S 15,20$ Stat. 145, 152. 
Carolina he claimed had amounted to insurrection, so he relied upon the very old statute now codified as 10 U.S.C. section 331 for his utilization of troops there. With regard to certain instances in several other states, he relied for justification upon the Civil War and Reconstruction Era statutes now codified as 10 U.S.C. sections 332 and 333, and upon the terms of a section of the Enforcement Act of 1870, discussed earlier, ${ }^{105}$ which has since been repealed. As to certain other situations, Grant claimed simply to have made troops available to be used as a posse in accordance with the traditional practice-although the critical distinction between distinctively military and civilian character, which had been the essential feature of that traditional practice, by then had been neglected in practice for many years.

Most notably, however, for circumstances not coming within any of the foregoing justifications, this General who had directed the whole process of Reconstruction before becoming President now asserted a "power as commander of the Army and Navy to prevent or suppress resistance to the laws of the United States. . . "108 "The companies stationed in the other States," he declared, "have been employed to secure the better execution of the laws of the United States and to preserve the peace of the United States."157 In support of this assertion of executive power not derived from any statute, Grant referred to a hodgepodge of historical incidents-all of which, however, actually were applications either of one of the statutes or else of the traditional posse comitatus practice. In substance, President Grant was making an unprecedented claim of inherent executive power to employ military force to execute the laws and preserve domestic peace.

Congress's response to Grant's king-like assertion of inherent executive power to enforce the laws by military means was a flat repudiation of the claim: the Posse Comitatus Act declared:

From and after the passage of this act it shall not be lawful to employ any part of the Army of the United States as a posse comitatus, or otherwise, for the purpose of executing the laws, except in such cases and under such circumstances as such employment of said force may be expressly authorized by the

155. See supra text accompanying note 125 .

156. G. LIEBER, supra note 151 , at 9.

157. Id. at 8. 
Constitution or by act of Congress. ${ }^{168}$

Although its popular name tends to focus attention solely upon the posse concept, it is important to note that the Act forbids the use of the Army as a posse, "or otherwise," to execute the laws, except as expressly authorized.

The various existing statutory authorizations, despite the constitutional defects to be found in most of them, were left undisturbed by this Act. Its whole purpose was to put an end to the extra-statutory practices which President Grant had sought to justify. The critical word in the Act adapted to accomplish this purpose was the word "expressly."158 The traditional practice of using troops as a posse in accordance with the Mansfield Doctrine had been authorized by Congress; that was the function of section 9 of the old 1792 Act, ${ }^{160}$ and even though the important interplay between that section and section 2 of the old Act had been destroyed by the revisions made in $1861,{ }^{181}$ the substance of old section 9 still remained on the books when the Posse Comitatus Act was passed. Nevertheless, while it is plain from its history that authorization of the posse practice was the entire purpose of that old statutory provision, its terms did not "expressly" authorize any use of troops. Consequently, the 1878 Act immediately put an end to the practice of federal marshals

158. Act of June 18, 1878, ch. $263, \S 15,20$ Stat. 145,152 (emphasis added). As it survives in the Code today, the Posse Comitatus Act provides:

Whoever, except in cases and under circumstances expressly authorized by

the Constitution or Act of Congress, willfully uses any part of the Army or the

Air Force as a posse comitatus or otherwise to execute the laws shall be fined not more than $\$ 10,000$ or imprisoned not more than two years, or both.

18 U.S.C. 1385 (1976).

159. The Act originated in the House, with language which would have limited the use of the Army or Navy to situations "expressly" authorized by Congress. 7 Cong. Rec. 3586 (1878). Reference to naval forces was dropped, doubtless because the appropriations bill under consideration was only for the army, 7 CoNG. REc. 3578-79, 3877 (1878). The Senate approved the measure on the second day of debate, 7 CoNG. REc. 4302 (1878), but only after Senate Republicans had excised the word "expressly," 7 Cong. REc. 4246-48 (1878), and added provision for situations that might be authorized "by the Constitution," 7 Cong. Rec. 4240 (1878). The House, however, refused to accept any such weakening of the prohibition they meant to impose. Reference to purported constitutional authorization would be harmless if the word "expressly" were restored, for the Constitution contains no "express" authorization for such use in the absence of a statute. See infra notes 163-65 and accompanying text. Restoration of the word "expressly," however, was crucial, and in conference the House conferees insisted upon its reinsertion, see 7 Cong. REc. 4686 (1878). In the end, the Senate yielded on the matter, and before final enactment the critical word "expressly" was restored to the text.

160. See supra text accompanying notes 72-78.

161. See supra text accompanying notes 80-81, 92-96. 


\section{using army troops as their posse. ${ }^{162}$}

The Act also excepted from its prohibition such use of the army as might be "expressly authorized by the Constitution." The only provision in the Constitution dealing "expressly" with any domestic use of the military, ${ }^{16 s}$ however, is article I, section

162. Less than four months after the Posse Comitatus Act was adopted, the Attorney General in a formal opinion entitled "Employment of the Military as a Posse," wrote as follows:

It has been the practice of the government since its organization ( 80 far as known to me) to permit the military forces of the United States to be used in subordination to the marshal of the United States when it was deemed necessary that he should have their aid in order to the enforcement of his process. This practice was deemed to be well sustained under the twenty-seventh section of the judiciary act of 1789 [see supra note 73 and accompanying text], which gave to the marshal power 'to command all necessary assistance in the execution of his duty, and was sanctioned not only by the custom of the Government, but by several opinions of my predecessors. Instructions given by my predecessor, the Hon. William M. Evarts, of date August 20, 1868, state particularly the authority of the marshal in this regard, and call attention to the fact that the military in such case obey the summons of the marshal as a posse comitatus and act in subordination and obedience to the civil officer in whose aid in the execution of process they are called, and only for the object of securing its execution.

While the right to summon a portion of the military forces where it can be spared for the duty, as a part of the posse comitatus, is fairly to be inferred from the provision in the judiciary act which I have already quoted, there is found, however, no express authority by which the marshal may summon any military force of the United States as a part of the posse comitatus.

16 Op. Att'y Gen. 162-63 (1878). He therefore concluded that the new Act forbade it. Id. at 163. Two and one half years later the Attorney General advised that because of the Act it would be impermissible to use "a detachment of troops to aid the civil authorities in arresting certain persons in the State of Kentucky who are charged with the recent robbery of the clerk of the engineer officer superintending the Government works on the Tennessee River. . ." 17 Op. Att'y Gen. 71 (1881). Other opinions barred the posse practice on account of the Act in the Territory of Arizona, id. at 242 (1881), 17 Op. Att'y Gen. 333 (1882); in the Territory of Oklahoma, 19 Op. Att'y Gen. 293 (1889); and in the Territory of Alaska, id. at 368 .

The traditional use of soldiers as a posse persisted, however, with regard to state military forces and state officials, see, e.g., State v. Coit, 8 Ohio Dec. 62 (1897).

163. None of the constitutional clauses commonly relied upon by apologists for military law enforcement "expressly" - or, for that matter, even implicitly-authorizes the executive to use the military to execute the laws, or to aid civil authorities in doing so. The United States Constitution, article II, \& 3, requires that the President "take Care that the Laws be faithfully executed," but does not even remotely suggest that he may use the military for that purpose. Article II, § 2, makes the President Commander-inChief of the armed forces, but does not indicate that he may use these instruments of war either to assist or to displace the agencies of civil law enforcement. See supra note 7. Moreover, since Congress is given power legislatively to determine how to carry into execution even this Commander-in-Chief power, see Article I, $\$ 8, \mathrm{cl}$. 18, it is impossible to claim the Commander-in-Chief clause as "express" constitutional authorization to the 


\section{8 , clause $15 ;^{184}$ and that clause only gives to Congress the power}

executive to use the armed forces contrary to the will of Congress.

The "guaranty clause," article IV, § 4, provides that "the United States" shall guarantee each state, upon its request, "against domestic Violence." This power and duty, however, is conferred by the Constitution not upon the executive, but upon "the United States;" and article I, \& 8, cl. 18 gives Congress power to provide by legislation for carrying into execution all powers "vested by this constitution in the Government of the United States, or in any Department or Officer thereof." The guaranty clause, therefore, cannot be viewed as "express" constitutional authorization for the executive to do anything otherwise forbidden by Congress.

Careful study of the records of the Constitutional Convention indicates that the draftsmen, in using the term "domestic Violence" in the guaranty clause (and also in authorizing Congress to provide for use of the militia "to execute the Laws of the Union," article I, $\S 8$, cl. 15), probably had in mind only situations of treasonous violence, i.e., insurrection. See the analysis of the Convention records in Soldiers, Riots, and Revolution, supra note 14, at 35-39. Alternatively, it is possible that the draftsmen had in mind the Mansfield Doctrine, which provided for use of troops as civilians in situations of noninsurrectionary violence; see The New Civil Disturbance Regulations, supra note 14, at 588. At least there is nothing in the guaranty clause that expressly authorizes any use of military force to deal with domestic violence less than insurrection. Indeed, it was precisely to safeguard against the risk that this clause (and the clause contemplating militia execution of federal laws) might be construed to authorize military force to suppress non-insurrectionary violence that the Bill of Rights, including the fifth amendment's guarantee of civilian due process, was adopted. See supra text accompanying notes 21-44. Any notion that the guaranty clause, after adoption of the Bill of Rights, could be construed to authorize military measures to deal with non-insurrectionary violence was (or ought to have been) dispelled by the contemporaneous construction of that language reflected in the earliest congressional legislation, see supra text accompanying notes 51-66 and 68-83.

The demise of the Mansfield Doctrine has made it impossible to apply the law execution language of article I, $\& 8, \mathrm{cl}$. 15 consistently with due process, other than to instances of insurrectionary resistance to federal laws. The "domestic Violence" language of the guaranty clause, however, need not be construed as confined to insurrections, because it does not expressly authorize military measures. The protective duty imposed by this clause can be amply fulfilled as to violence not amounting to insurrection (e.g., as to riots and civil disorders) without offending the due process prohibition against military measures. Even though the Mansfield Doctrine has been forgotten (and even though the Posse Comitatus Act would now preclude such posse use of troops anyway), Congress certainly has power by virtue of the guaranty clause and the necessary and proper clause to provide for civilian federal assistance for riot and disorder suppression. Congress could authorize the use of federal marshals, or some specialized group of them, like the Marshals' Service Special Operations Group. Congress could authorize use of agents of the Federal Bureau of Investigation, or Treasury Department agents, or could create a federal civilian police force specifically for the purpose. Congress could set up a system for interstate lending of police resources, or even provide for "federalizing" police resources from sister states. The necessary and proper clause and the supremacy clause are ample to surmount any objections of "state sovereignty." The impediments to these civilian means of federal suppression of violence are limitations of congressional imagination, not constraints of constitutional law. All that is forbidden is the one expedient that has, by default of imagination, become the norm: the use of the military to execute the laws.

164. "The Congress shall have Power . . . To provide for calling forth the Militia to execute the Laws of the Union, suppress Insurrections and repel Invasions." U.S. Const. 
to provide for calling forth the militia to execute the laws of the Union. This, as much as the other provisions cited earlier, ${ }^{165}$ confirms the power of Congress over the matter, and negates any concept of inherent executive authority to use military force to execute the laws. As plainly, therefore, as it prohibited any continuation of the traditional practice of using army troops as a posse, the 1872 Act prohibited their being used "otherwise" pursuant to the notion of inherent executive power which had been propounded by President Grant, and is now relied upon by the Civil Disturbance Regulations.

The language confining the exceptions from its prohibition to those "expressly" provided by Constitution or statute remains in the current version of the Posse Comitatus Act in force today. ${ }^{168}$ The new Regulations pretend that the notion of a constitutionally implied extra-statutory "emergency authority" is consistent with this Act, but the pretense is too transparent; in reciting the substance of the Act's prohibition, the new Regulations notably omit the word "expressly."167

Because the Posse Comitatus Act when enacted was a rider to the Army Appropriation Act of 1878 (and because it was not the navy that had been misused) it was only the use of "any part of the Army" that the original language proscribed. ${ }^{168}$ Decades later the Army Air Corps developed and then spun off as a separate branch of the armed services; and, when that happened, Congress amended the Act to specify "any part of the Army or the Air Force,"189 putting the statute into the form in which it remains today. A bill which died of neglect in the Congress a decade ago would have broadened the language to include any part of "the Armed Forces of the United States;"170 but decades of consistent administrative construction had already given the narrower language that broader effect. It was well understood, as the legislative history of the Posse Comitatus Act makes clear, ${ }^{171}$ that the Act was an attempt by Congress to reassert the civilian constitutional principle restraining the domestic use of any mili-

art. I, \& 8, cl. 15.

165. See supra notes 145 and 146 and accompanying text.

166. See supra note 158 .

167. 32 C.F.R. 215.4(b) (1981).

168. See supra note 159 .

169. Act of August 10, 1956, ch. 1041, $\S 18(a), 70$ A Stat. 626.

170. S. 2318, 93rd Cong., 1st Sess. (1973).

171. 7 Cong. Rec. 3845-52, 4239-48, 4295-4305 (1878). 
tary force. Thus, the Navy Department long ago by regulation adopted an equivalent prohibition, making specific reference to the Act, and in 1974 the Fourth Circuit Court of Appeals held that Navy regulation to have been violated when the Treasury Department used three enlisted Marines as undercover investigators of federal firearms law violations. ${ }^{172}$ Consistent with this long established view of the import of the Posse Comitatus Act, the 1968 Civil Disturbance Regulations had declared that "[a]lthough the Navy and Marine Corps are not expressly included within its provisions, the Act is regarded as national policy applicable to all military services of the United States."178 The 1972 Regulations, however, notably omit any such statement ${ }^{174}$-another indication of the ominous new determination to enlarge the possibilities of military intervention as far as possible beyond previous bounds.

Although now more than a century old, the Posse Comitatus Act is no mere relic of history as far as Congress is concerned. That Act, and the jealous watch against military involvement in domestic law enforcement which it represents, was paramount in the deliberations of Congress during 1981 when it considered and adopted section 905 of the Department of Defense Authorization Act of 1982. ${ }^{175}$ The enactment of section 905 on December 1, 1981, added sections 371 through 378 to title 10 of the United States Code. These new statutory provisions are notable in certain respects as authorizing limited law enforcement use of military resources where no such statutory authorization had existed before. The new provisions are far more notable, however, for the deliberate refusal of Congress, in enacting them, to countenance any such use of military resources as the "emergency authority" pretended by the Civil Disturbance Regulations portends.

The new provisions thus added to title 10 of the United States Code authorize the Secretary of Defense, for the first time, to "make available any equipment . . . of the Army, Navy, Air Force, or Marine Corps to any Federal, State, or local civilian law enforcement official for law enforcement purposes."176 They also authorize the Secretary to assign members of the

172. United States v. Walden, 490 F.2d 372 (4th Cir. 1974).

173. 32 C.F.R. $\S 187.4$ (b) (1971).

174. 32 C.F.R. § 215.4 (b) (1981).

175. P.L. 97-86, 95 Stat. 1115 (1981).

176. 10 U.S.C. $\$ 372$ (1981). 
armed forces "to train Federal, State, and local civilian law enforcement officials in the operation and maintenance of equipment made available under [the provision just quoted] and to provide expert advice relevant to" the use of that equipment for law enforcement purposes. ${ }^{177}$ Such Defense Department equipment, training, and advice had occasionally been made available prior to this 1981 statutory authorization; and in enacting these provisions Congress believed, as was testified by administrative personnel, that the new legislation merely "clarifies existing administrative practice." 178 Such prior practice as had existed with regard to making military equipment available for civilian law enforcement, however, actually had been without any authority in law. ${ }^{178}$

177. 10 U.S.C. $\S 373$ (1981).

178. H. REP. No. 71 (II), 97th Cong., 1st Sess. 9-10, reprinted in 1981 U.S. Code Cong. \& AD. News 1791, 1792.

179. The Posse Comitatus Act foreclosed the use of "any part of" the Army or Air Force to execute the laws, except as "expressly" allowed. The use of an Air Force helicopter and its Air Force crew to search for an escaped prisoner, for example, has been held to be a violation of the Act, the Court observing:

The innocence and harmlessness of the particular use of the Air Force in the present case, the dissimilarity of that use to the uses that occasioned the enactment, these considerations are irrelevant to the operation of a statute that is absolute in its command and explicit in its exceptions.

Wrynn v. United States, 200 F. Supp. 457, 465 (E.D.N.Y. 1961). What inflamed revolutionary passions in eighteenth century New England was precisely the soldiers' red tunics, army muskets, and bayonets. In old England the men who served as the civilian posse and who served as the King's soldiers were the same men; what gave rise to Magna Carta and its insistence that civil law be enforced by the law of the land rather than by military measures was precisely the equipment that was used: helmet and breastplate and broadsword and lance--the instruments of war-had no place in domestic law enforcement.

It was alarm not only over military personnel but over the appearance of military equipment in domestic law enforcement situations that led to enactment of the Posse Comitatus Act. At that time, no one actually conceived that military armaments might be loaned out and borne by civilian officials rather than soldiers, but the legislative history of the Act shows that it was the weapons and conveyances and trappings of the Army, as much as or more than the persons of the soldiers, that was the focus of the Act.

In the House, for example, Congressman Robertson of Louisiana spoke from his personal observation of the "moral interference" of military accoutrements: the intimidation of newly enfranchised black voters by squads of soldiers purportedly exercising themselves and their horses, riding through the parish and past the polling place "armed and equipped, . . . in the uniform of the United States troops and with their cartridge-boxes and arms." 7 CoNG. REc. 3852 (1878). Immediately after Congressman Robertson's comments, debate on the measure ceased and it was approved. Id.

In the Senate, on the first day of deliberations there was discussion of military activities not only intimidating electors but also combating illegal distillers to enforce the federal revenue laws, and controlling labor unrest. When Senator Edmunds of Vermont opposed the measure on the ground that some organized body must be available for 
More significant than the new legislation's first-time authorization of such loans of military equipment (and training in its maintenance and operation), however, is its denial for purposes of any other law enforcement application of certain additional elements of military assistance it guardedly made available for enforcing a few specified federal immigration, customs, and drug laws. As to the latter few laws only, the new legislation provides that in certain statutorily defined "emergency circumstances," and pursuant to a cabinet-level request for assistance, military personnel themselves may be permitted to operate or maintain the military equipment made available to the civilian authorities. ${ }^{180}$ Even in such exceptional situations, however, the new legislation precludes the "direct participation" of military personnel in law enforcement activities. ${ }^{181}$ Moreover, military personnel may be used in connection with such equipment even with respect to enforcement of those few specified statutes, "only to the extent the equipment is used for monitoring and communicating the movement of air and sea traffic,"182 or when it is used "outside the land area of the United States . . . as a base of operations" for federal civilian officials enforcing the drug, customs, or immigration laws, "and to transport such law

national law enforcement, and that soldiers are no different from a conventional posse, 7 Cong. Rec. 4241-42, 4244-46 (1878), Senator Wallace of Pennsylvania met his argument with a hypothetical pointing up the distinction by reference, not to the persons of the soldiers, but to their equipment, their arms. Suppose, Senator Wallace suggested, "a battery of artillery" brought to Scranton to deal with "difficulty among the laboring men." 7 Cong. REc. 4246 (1878). The distinction between military and civilian equipment explains why so many of the Senators in $\mathbf{1 8 7 8}$ found the whole notion that soldiers might be used as a posse, as contemplated by the subtle and by then long forgotten Mansfield Doctrine, to be incomprehensibly odd.

Thus, until the 1981 legislation there was never any basis in law for the idea that military equipment (not to mention military operators and support personnel) could be used for civil law enforcement without offense to the Posse Comitatus Act. The prohibition was categorical; it precluded the use of "any part."

Congress included in the section of its 1981 legislation authorizing the Secretary to make Defense Department equipment available the phrase, "in accordance with other applicable law," 10 U.S.C. \$ 372 (Supp. V 1981), contemplating in particular the Economy Act, 31 U.S.C. 686. See H.R. REP. No. 71 (II), 97th Cong., 1st Sess. 9, reprinted in 1981 U.S. Codr Cong. \& Ad. News 1792. The Economy Act could not be regarded as authority for making such equipment available, see infra text accompanying notes 235 41; but it does prescribe procedures appropriate to be followed when loans of equipment authorized by the new Act are made.

180. 10 U.S.C. § 374 (Supp. V 1981).

181. 10 U.S.C. $\$ 375$ (Supp. V 1981).

182. 10 U.S.C. $\$ 374$ (b) (Supp. V 1981). 
enforcement officials in connection with such operations."183 The limitation to activities "outside the land area of the United States," resulted specifically from Congress's insistence upon "[t]he traditional opposition to military participation in U.S. law enforcement activities," which "does not exist to the same extent when that participation occurs overseas."184

It is clear from numerous passages in the relevant committee reports that Congress in 1981 was acting on the premise that, but for the specific authorization given by this new legislation, even such minimal use of military personnel as having them maintain or operate the military equipment made available to civilian officials for law enforcement would have violated the Posse Comitatus Act. The decision by Congress to grant such authorization only in connection with federal drug, immigration, and customs laws, and even in that connection to require both a cabinet-level request and a demonstrable "emergency circumstance" satisfying a two-part statutory test, and even then to restrict such use of military personnel (except with regard to air and sea traffic monitoring equipment) to places "outside the land area of the United States," and in any event to ensure against their "direct participation" in any law enforcement activity, seems rather persuasively to suggest a firm congressional resolve to maintain, with only the most limited and carefully guarded exceptions, the otherwise categorical prohibition of the Posse Comitatus Act.

As the Posse Comitatus Act was Congress's repudiation a century ago of President Grant's claim of inherent executive power to use military force in exigent circumstances to execute the laws and maintain peace and order, so might its 1981 action be properly viewed as Congress's repudiation of the claim of "emergency authority" propounded in the 1972 Civil Disturbance Regulations.

The will of Congress, however, is not always respected by the executive branch. The Department of Defense regulations on "DOD Cooperation With Civilian Law Enforcement Officials," added to title 32 of the Code of Federal Regulations in 1982,185 purport to be consistent with the requirements of 10 U.S.C. sec-

183. 10 U.S.C. $\$ 374(c)$ (Supp. V 1981).

184. H.R. REP. No. 71(II), 97th Cong., 1st Sess. 17, reprinted in 1981 U.S. CodE Cong. \& AD. News 1785, 1798 (separate views of Reps. John R. Seiberling and Don Edwards regarding language later moved and approved on the floor).

185. 32 C.F.R. $\$ 213$ (1982). 
tions 371-78; although in many respects they are consistent, in many respects they are not. Section 213.10 of these newest regulations retaliates against the latest congressional reaffirmation of the prohibition against military intervention with a catalogue, more extensive than any previously published anywhere, of circumstances in which the Posse Comitatus Act allegedly does not apply. Section 213.10 (a)(2) lists in four categories, with a total of twenty-two separately itemized subcategories (in addition to 10 U.S.C. sections 331-33), activities which, according to the Department of Defense, "are not restricted by the Posse Comitatus Act . . ., notwithstanding direct assistance to civilian law enforcement officials." (emphasis added). By "direct assistance" the regulation contemplates the use of military personnel in a variety of actions including arrest, stop and frisk, interdiction of a vehicle, pursuit, surveillance, investigation, and interrogation. ${ }^{188}$ These are the very activities which Congress directed that even those military personnel assigned in a defined "emergency circumstance" to operate loaned equipment used "outside the land area of the United States" to enforce the immigration, drug, or customs laws must assiduously avoid. ${ }^{187}$ While Congress regarded its authorization of unusual military aid with respect to the latter few laws as an extraordinary measure for dealing with peculiar and chiefly extraterritorial problems, and even so to be guarded with stringent restrictions, the executive branch by 32 C.F.R. section 213.10 treats it as the one circumscribed anomaly among a host of carte blanche authorizations for military intervention in law enforcement affairs.

Some of the circumstances in which this newest regulation claims that the Posse Comitatus Act is no bar are indeed circumstances in which military assistance has been authorized expressly by Congress. These express authorizations include not only 10 U.S.C. sections $331-33$, but also a number of very specialized statutes-statutes which in fact are more specialized and more limited than the Defense Department regulation acknowledges them to be. ${ }^{188}$ Several other circumstances are

186. 32 C.F.R. $\S 213.10(3)(1982)$.

187. 10 U.S.C. $\$ 375$ (Supp. V 1981).

188. Citations to these statutory provisions are set out in 32 C.F.R. $\S$ 213.10(a)(2)(iv). The very limited scope of two of the cited statutes (18 U.S.C. $\$ 351$ (Supp. V 1981) and 18 U.S.C. $\$ 1751$ (1976) and the irrelevance of a third (18 U.S.C. \& 3056 (Supp. V 1981)) are discussed infra note 209 and accompanying text.

Some of the others are of dubious validity under the constitutional rule discussed in 


\section{grouped under the heading of "actions that are taken for the}

this article, although some of the oldest of these might have stood constitutional muster under the circumstances of an earlier day. For example, 43 U.S.C. $\$ 1065$ (1976) authorizes the President to use either civil or military force "to remove and destroy any unlawful enclosure of any of the public lands . . . ." This provision was enacted in 1885, when there were still substantial tracts of public land in areas where little or no effective civil authority was present. Another example is 25 U.S.C. $\$ 180$ (1976), which authorizes the President to employ military force to remove persons settling on lands belonging by treaty to any Indian tribe; this provision was enacted in 1834 . Title 16 U.S.C. $\$ \S 23$ and 78 (1976) authorize the use of troops to remove intruders from, or to prevent them from entering, Yellowstone, Sequoia, or Yosemite National Parks "for the purpose of destroying the game or objects of curiosity therein, or for any other purpose prohibited by law;" a cabinet level request is required. The Yellowstone provision ( $\$ 23)$ was enacted in 1883 , and the Sequoia and Yosemite provision $(\$ 78)$ in 1900 . (The 1982 regulation also cites in this connection 16 U.S.C. $\$ 596$, which, however, was repealed in 1933.)

Title 42 U.S.C. $\S 1989$ (1976) authorizes use of military assistance by persons appointed by magistrates to execute warrants or other process issued pursuant to certain civil rights laws. This provision is a remnant of $\$ 5$ of the Civil Rights Act of 1866 , the dubious constitutionality of which has already been discussed in the text accompanying supra notes 103-05.

Title 48 U.S.C. $\$ 1422$ (1976) (as to Guam) and 48 U.S.C. $§ 1591$ (1976) (as to the Virgin Islands) authorize the governors of those territories to request military assistance not only to deal with insurrection or rebellion but also "to prevent or suppress lawless violence." Insofar as these provisions are deemed applicable to mere riot or civil disorder, they seem subject to the same constitutional doubts noted with regard to 10 U.S.C. $\S 332$ (1976), see supra text accompanying notes 68-98.

Title 50 U.S.C. $\$ 220$ (1976) authorizes the use of parts of the Army or Navy in extraordinary circumstances to prevent the removal of vessels or cargo from the custody of customs officials. This provision was enacted in 1861 with reference to difficulties encountered at the threshold of the Civil War, and is codified now (as it was in the Revised Code of 1878) under the heading, "Insurrection." To construe it as applicable in any situation not constituting an armed assault disabling the civilian organs of government would present the same constitutional difficulties discussed in connection with 10 U.S.C. § 331 (1976), see supra text accompanying notes 50-67.

Title 42 U.S.C. $\$ 97$ (1976), originally enacted as Act of Feb. 23, 1799, ch. 12, § 1, 1 Stat. 619, requires "military officers commanding in any fort or station upon the seacoast" to obey quarantines and other regulations imposed by state health laws respecting vessels arriving at the ports of such states. It also provides that such officers "shall faithfully aid in the execution of such quarantines and health laws," but only "according to their respective powers and within their respective precincts." It thus does not authorize any action otherwise outside the military officer's powers, and hence does not authorize any action on their part enforcing the laws against civilians.

Title 18 U.S.C. $\S \S 112$ and 1116 (1976) authorize the Attorney General to request military assistance to enforce the federal laws prohibiting assaults and homicides against the persons and families of foreign officials, foreign nationals who are official guests designated by the Secretary of State, and other persons who by international law are entitled to special protection. The authorization for military assistance in these circumstances was enacted in 1976, the same legislation also authorizing requests for the assistance of any civilian agency, federal, state, or local. The purpose of the legislation was to ensure that the United States could fulfill obligations under international conventions against terrorism. The legislative history indicates that such requests should be made only in exceptional instances: "There may be circumstances-such as the takeover of an embassy - when the Justice Department will need assistance from other federal, 
primary purpose of furthering a military or foreign affairs function of the United States, regardless of incidental benefits to civilian authorities."189 Most significantly, however, this newest regulation includes among those circumstances in which even "direct assistance" of military personnel purportedly can be provided without violation of the Posse Comitatus Act, circumstances coming within "the emergency authority" pretended by the 1972 Civil Disturbance Regulations. ${ }^{190}$

Thus, although promulgated under color of implementing Congress's 1981 legislation (by which Congress sought to reaffirm its 1878 repudiation of any executive emergency military law enforcement prerogative), these newest regulations actually reiterate the executive's claim to precisely that same prerogative, asserted under the label "emergency authority" in the Civil Disturbance Regulations of 1972.

\section{B. The Purported "Protective Power"}

The 1972 Civil Disturbance Regulations also assert that the Constitution, without the aid of any statute "[a]uthorizes Federal action, including the use of military forces, to protect Federal property and Federal governmental functions when the need for protection exists and duly constituted local authorities are unable or decline to provide adequate protection." 191 The 1968 Regulations had provided that military forces could be used to protect federal property and federal facilities, but had

State, or local agencies." H.R. Rep. No. 1614, 94th Cong., 2d Sess. 5, n.7, reprinted in 1976 U.S. Code Cong. \& AD. News, 4480, 4483. Even so, the constitutionality of such military assistance is dubious.

Title 48 U.S.C. $\S 1418$ (1976) authorizes use of the armed forces to protect the rights of discoverers of guano islands, extraterritorial islands considered, at the discretion of the President, to appertain to the United States.

Title 22 U.S.C. $\S \S 408$ and 461-62 authorize the use of the military to help enforce the neutrality laws, preventing the illegal export of war materiel and the launching of illegal expeditionary forces against foreign powers.

Title 16 U.S.C. $\$ 1861$ (1976) authorizes use of military personnel, services, equipment (including aircraft and vessels) and facilities to enforce the fishery conservation laws at sea.

Title 42 U.S.C. ] 378]9 (Supp. III 1979) authorizes the Law Enforcement Assistance Administration (LEAA) to use "the available services, equipment, personnel, and facilities of" other civilian or military agencies "in the establishment and use of services, equipment, personnel, and facilities of the Administration." LEAA, however, has no law enforcement authority. 42 U.S.C. $\$ 3709$ (d)(a) (1976).

189. 32 C.F.R. $\S 213.10(\mathrm{a})(2)(\mathrm{i})(1982)$.

190. 32 C.F.R. \& 213.10 (a)(2)(ii)(A) (1982).

191. 32 C.F.R. \& 215.4(c)(1)(ii) (1982). 
premised such use upon one of the statutes previously discussed, 10 U.S.C. section $332 .{ }^{192}$ That application of section 332 was itself constitutionally dubious insofar as it failed to acknowledge the incapacitation of civilian means as a necessary precondition; ${ }^{109}$ but at least the 1968 Regulations had made no claim to an extra-statutory "protective power."

It may be conceded that the federal government has power, conferred by the Constitution, to protect federal property and functions. That concession, however, does not obviate the question of how this admitted power is distributed among the three branches of the federal government. It is upon Congress that the Constitution confers power to make rules and regulations respecting federal property, ${ }^{194}$ and to make laws necessary and proper to effectuate federal functions; ${ }^{190}$ the executive is authorized merely to "take care that the Laws be faithfully executed." 198 As already noted in the preceding discussion concerning the broader claimed "emergency authority," there are a few things that the executive might do to protect federal property or federal governmental functions in the absence of any relevant legislation. There is absolutely nothing in the Constitution, however, suggesting that the executive's action in such instances, where the threat is domestic, may take military form. ${ }^{197}$ In any event, the power to make laws for the protection of federal property and functions being unequivocally conferred upon Congress, any power the executive might have to the same ends is clearly subject to such strictures as Congress might impose. ${ }^{198}$ Therefore, even if the due process clause of the fifth amendment were not a categorical prohibition against law enforcement use of the military, such use of the military to protect federal property and functions could not be made in the face of a statutory prohibition.

The Posse Comitatus Act, therefore, is as much a repudiation of the extra-statutory "protective power" claimed by the 1972 Civil Disturbance Regulations as it is of the broader "emergency authority" those Regulations claim.

192. See, e.g., 32 C.F.R. § 187.5(a)(1) (1971).

193. See supra text accompanying notes 68-98.

194. U.S. Const. art. IV, $\S 3$, cl. 2.

195. U.S. Const. art. I, $\S 8$, cl. 18.

196. U.S. Const. art. II, § 4.

197. See supra notes $141-43$ and accompanying text.

198. See Youngstown Sheet \& Tube Co. v. Sawyer, 343 U.S. 579 (1952). 
Nonetheless, the 1982 regulations concerning "DOD Cooperation With Civilian Law Enforcement Officials" boldly reassert this "protective power" falsely claimed by the Civil Disturbance Regulations. ${ }^{198}$ Indeed, the 1982 regulations repeat with new emphasis the 1972 Regulations' assertion that both the "protective power" and the "emergency authority" arise under "the inherent right of the U.S. Government, a sovereign national entity under the U.S. Constitution, to ensure the preservation of public order and the carrying out of governmental operations within its territorial limits, by force if necessary." ${ }^{200}$ The assertion is that these prerogatives inhere in the national government by virtue of sovereignty and the Constitution; but nothing in either implies that they inhere in the executive branch of that government. On the contrary, the Constitution specifically vests in Congress the power to determine when and how the armed forces may be used. ${ }^{201}$ What Congress has said is that military resources may be used only when "expressly authorized by the Constitution or Act of Congress,"202 and nothing anywhere in the Constitution (much less in any concept of "sovereignty") expressly authorizes extra-statutory utilization of military resources by the executive in any domestic situation, whether there be some "emergency" or some need for "protective" action, or otherwise. Congress's insistence upon rigorous adherence to its century-old repudiation of all pretense to any inherent executive power to use the military for law enforcement is manifest both in the letter and in the legislative history of the new legislation enacted in December 1981, on which these latest Defense Department regulations purport to be based. Yet the regulations regard that repudiation, insisted upon by Congress, as having no effect. The thrust of the latest regulations is simply that the executive will use military force whenever the executive deems it expedient to do so, congressional prohibitions notwithstanding.

\section{House Joint Resolution 1292}

The sixth and last basis claimed ${ }^{203}$ for the Civil Disturbance

199. 32 C.F.R. $\S 213.10$ (a)(2)(ii)(B) (1982).

200. 32 C.F.R. $\S 213.10$ (a)(2)(ii) (1982) (paraphrasing 32 C.F.R. $\S 215.4$ (c)(1) (1982)).

201. See supra notes $163-65$ and accompanying text.

202. The Posse Comitatus Act, 18 U.S.C. § 1385.

203. 32 C.F.R. $\S 215.4(c)(2)(i)(D)$ (1981). 
Regulations is House Joint Resolution 1292, adopted June 6, 1968. Although this Resolution had been adopted before the 1968 Civil Disturbance Regulations had been promulgated, those earlier Regulations had not claimed it as authority; but the 1972 Regulations do.

Section 2 of House Joint Resolution 1292 provides that:

Hereafter when requested by the Director of the United States Secret Service, Federal Departments and agencies, unless such authority is revoked by the President, shall assist the Secret Service in the performance of its protective duties under section 3056 of title 18 of the United States Code and the first section of this joint resolution. ${ }^{204}$

The duties of the Secret Service in connection with which the assistance called for by this Resolution is to be given include enforcement of a variety of laws concerning fraud, counterfeiting, forgery, and embezzlement affecting currency, government securities, and funds and obligations of federally chartered and federally insured financial institutions. Far more significant, however, these duties include protection of the persons of the President and Vice President, as well as the President-elect, the families of the President and former Presidents, and major Presidential and Vice Presidential candidates. In the performance of these duties the Secret Service and its agents are empowered to make warrantless arrests on reasonable grounds of belief with regard to any felony under federal law, and warrantless arrests for any lesser federal offense committed in their presence. ${ }^{205}$

Presidents, past Presidents, their families, and candidates are familiar targets not only for demented eccentrics but also for political extremists seeking to excite or exploit civil turmoil. The fact or reasonable suspicion of some radical plot might easily be taken to justify extensive surveillance or enforcement activities by the Secret Service. Such activities by the civilian Secret Service might not be cause for alarm; but, if the armed forces could then be called upon to aid the Secret Service in its task, a far different situation would be at hand. The new Civil Disturbance Regulations claim House Joint Resolution 1292 as authority for invoking such military aid, even without any personal presidential action, merely on the request of the Secret Service Director.

204. Pub. L. 90-331, 82 Stat. 170 (1968). The Resolution has not been codified; it is set out in the notes to 18 U.S.C. $\S 3056$ (1976).

205. 18 U.S.C. \& 3056 (Supp. III 1979). 
Reliance upon this Resolution as authority for military aid to the Secret Service, however, is misplaced for the same reason that the old legislation giving federal marshals powers equivalent to state sheriffs could not sustain the traditional posse use of troops after the Posse Comitatus Act: the Resolution does not "expressly" authorize it at all. The Resolution speaks generally of "Federal Departments and agencies;"206 and even though this phrase is of course broad enough to include the Department of Defense, there is no express indication that any of the military resources administered by that civilian department are to be comprehended. ${ }^{207}$

Ironically, the 1982 regulations on "DOD Cooperation With Civilian Law Enforcement Officials" make no reference whatever to House Joint Resolution 1292, even though they catalogue at extraordinary length all the statutory and purported extra-statutory exceptions to the Posse Comitatus Act prohibition. Among the statutory authorizations claimed by the new regulations to constitute exceptions to that prohibition, however, is 18 U.S.C. section 3056, ${ }^{208}$ the statute cited in House Joint Resolution 1292 as describing the protective duties of the Secret Service. 18 U.S.C. section 3056, however, makes no reference whatever to use of any military resources. Whether by virtue of that section itself or House Joint Resolution 1292, therefore, the assertion of authority to employ any military resources to aid in Secret Service protective duties is utterly without foundation in law, and is a naked affront to the will of Congress declared in the Posse Comitatus Act. ${ }^{208}$

206. See supra text accompanying note 204.

207. Nevertheless Mr. Justice Rehnquist, while he was an Assistant Attorney General, did advise the Army General Counsel that the Resolution could be regarded as an express exception to the Posse Comitatus Act prohibition. Unpublished Memorandum from Assistant Attorney General William H. Rehnquist to Hon. Robert F. Jordan III, General Counsel, Department of the Army (Nov. 12, 1968) (copy on file at United States Department of Justice).

208. 32 C.F.R. $\$ 213.10(a)(2)(i v)(E)$ (1981).

209. Title 18 U.S.C. $\$ 1751$ (1976) contains criminal provisions regarding assassination, kidnapping, and assault against the President and those in line of presidential succession. Subsection (i) provides that violations of the section "shall be investigated by the Federal Bureau of Investigation," and then adds that "[A]ssistance may be requested from any Federal . . . agency, including the Army, Navy, and Air Force, any statute, rule, or regulation to the contrary notwithstanding." On its face, however, this provision authorizes such aid of the military only with respect to investigation, and not with respect to any other enforcement activities. This is confirmed by S. REP. No. 498, 89th Cong., 1st Sess., reprinted in 1965 U.S. Code Cong. \& AD. News, 2866, 2867, which declares that the purpose of the provision "is to make clear that the Federal Bureau of 
V. The Blueprint for Intervention: Command and Control Under the New Civil Disturbance Regulations

The Civil Disturbance Regulations designate the Secretary of the Army (or the Under Secretary of the Army, as his designee) as "Executive Agent for the Department of Defense in all matters pertaining to the planning for, and the deployment and employment of military resources in the event of civil disturbances.""10 The Regulations call for this "Executive Agent" to establish a "Civil Disturbance Steering Committee," chaired by the Undersecretary of the Army, "to provide advice and assistance" to the "Executive Agent" "concerning civil disturbance matters." "The members of this "Steering Committee" include the Vice Chief of Staff of the Army, several other uniformed officers, some Defense Department officials, and the Deputy Attorney General of the United States. ${ }^{212}$

The "Steering Committee," however, does not exercise operational control. The Regulations call for the "Executive Agent" to establish "[a] Directorate of Military Support . . . with a joint service staff under the Chief of Staff, U.S. Army."21s With a Director drawn from the Army and a Deputy Director drawn from the Air Force, the Directorate of Military Support is to "plan, coordinate, and direct civil disturbance operations."

Investigation shall have jurisdiction over the investigation of violations of this act, and in the investigation of such violations may avail itself of the assistance of . . the Army, the Navy, and the Air Force. ...." (emphasis added).

Title 18 U.S.C. \& 351 (1976) is an equivalent provision enacted five years later, applicable to assassination, kidnapping, and assault against members and members-elect of Congress. This section originated as a Senate floor amendment to the Omnibus Crime Control and Safe Streets Act of 1970, and because it originated on the floor, is not illuminated by any committee reports; see CoNr. REP. No. 91-1768, reprinted in 1970 U.S. Cods Cong. \& AD. Nzws, 5842, 5849. The wording of 18 U.S.C. $\$ 351(\mathrm{~g})$ is identical to the wording of 18 U.S.C. $\$ 1751$ (i) (1976), after which it was patterned, and like the latter, manifestly contemplates the assistance of the military only with respect to investigation, and not with respect to any other enforcement activities.

210. 32 C.F.R. \& 215.6(a) (1981).

211. 32 C.F.R. \& 215.8(a) (1981).

212. Id. The Committee members are: Deputy Attorney General of the United States; Assistant Secretary of Defense (Comptroller); Assistant Secretary of Defense (Public Affairs); General Counsel of the Department of Defense; Under Secretary of the Navy; Under Secretary of the Air Force; Vice Chief of Staff of the Army; Vice Chief of Staff of the Air Force; Vice Chief of Naval Operations; Assistant Commandant of the Marine Corps; Representative of the Joint Chiefs of Staff; and the Under Secretary of the Army as Chairman.

213. 32 C.F.R. \& 215.8(b) (1981).

214. Id. 
The Regulations further provide that, with regard to disturbances within the continental United States, the "Executive Agent is delegated the authority to exercise, through the Chief of Staff, U.S. Army, the direction of those forces assigned or committed to him by the military departments."216 Under the Army Chief of Staff, "[a]t objective areas, designated task force commanders will exercise operational control over all military forces assigned for employment in the event of civil disturbances." It is through these "designated military commanders," responsible to the Army Chief of Staff and his Directorate of Military Support, that the "Executive Agent" exercises "the direction of military resources committed or assigned for employment in the event of actual or potential civil disturbances."217

What is contemplated, in other words, as to actual or potential disturbances, is a military chain of command from the Army Chief of Staff (or Vice Chief of Staff) through the Directorate of Military Support to the task force commanders and their troops, the only point of civilian control ${ }^{218}$ being at the top where the Secretary or Undersecretary of the Army acts as "Executive Agent" for the Department of Defense. ${ }^{219}$

According to the Regulations, the employment of military resources for controlling civil disturbances will "normally be predicated upon the issuance of a Presidential Executive order or Presidential directive authorizing and directing the Secretary of Defense to provide for the restoration of law and order in a specific State or locality."220 Indeed, apart from the Regulations, the statutes require that a Proclamation be issued by the President as a precondition to the use of troops under 10 U.S.C. sec-

215. 32 C.F.R. \& 215.8(a)(2) (1981).

216. 32 C.F.R. \& 215.7(c) (1981).

217. 32 C.F.R. $\& 215.6(a)(6)$ (1981) (emphasis added).

218. 32 C.F.R. $\S 215.5(e)$ (1981) provides that:

DOD components and their subordinated activities will coordinate with local civil authorities or local military commanders as appropriate, to assure mutual understanding of the policies and procedures to be adhered to in an actual or anticipated civil disturbance situation.

This coordination, however, in no way implies that the local authorities are to have any control over the federal military troops.

219. 32 C.F.R. $\$ 215.9$ (1981) deals with loans of federal military personnel and equipment to states, and precludes the use of any personnel so "loaned" in any "direct law enforcement role." Such "loaning" to states is beyond the subject of this article.

220. 32 C.F.R. § 215.5(a) (1981). 
tions 331,332 , or $333 .{ }^{221}$ The Regulations, however, provide for a major exception to this requirement of presidential involvement: No Presidential order or directive is needed, according to the Regulations, for instances within the purported "emergency authority," to deal with "[c]ases of sudden and unexpected emergencies ... . which require that immediate military action be taken."222 In such instances, no civilian higher than the "Executive Agent," the Secretary or Under Secretary of the Army, need be involved in the decision. Moreover, since the operational command role resides in the Army Chief of Staff and his Directorate of Military Support, even this minimal civilian role might well be more ephemeral than real. ${ }^{223}$ In other words, the "emergency authority" justification for military intervention, which is the most extraordinary and far-reaching power asserted by the new Civil Disturbance Regulations, may be invoked and implemented by the military itself with only a modicum (if even that) of civilian involvement.

Nor is this all. As the requirement of a Presidential order or directive is dispensed with, so also is the accompanying requirement that a "specific State or locality" be designated. ${ }^{224}$ Moreover, all of this pertains not only to "actual," but also to "potential" sudden emergencies requiring immediate military action. ${ }^{225}$ Although perhaps restricted somewhat by the terms of a Department of Defense Directive which is not available to the public, the Directorate of Military Support under the "Executive Agent" performs intelligence functions pertaining to planning in readiness for such actual civil disturbances as might sometime occur. ${ }^{226}$ Furthermore, the Regulations contemplate that, short of active military engagement, military ground forces may be "prepositioned" and held at the ready in case disturbances

221. 10 U.S.C. $\$ 334$ (1976). While. they reject this author's thesis that the use of military force for law enforcement violates the "due process of law" guarantee of the fifth amendment, even Pye \& Lowell, supra note 14, at 1094, urge that "The President should be required to issue an executive order whenever troops are utilized, stating the reasons for their deployment and the authority for his action." See also id. at 620 n.103.

222. 32 C.F.R. \& $215.5(a)(1)(1981)$.

223. It will be recalled that General Grant rather than the President was effectively put in command of the whole military reconstruction enterprise in the South after the Civil War, by the Act of Congress requiring that all orders pertaining to reconstruction measures be issued through him. See supra text accompanying notes 107-12.

224. 10 U.S.C. \& 334 (1976).

225. 32 C.F.R. $\S 215.6(a)(6)(1981)$, quoted supra in text accompanying note 217. 226. 32 C.F.R. $\S \S 215.6(a)(8), 215.6(a)(13)(1981)$. 
should arise. ${ }^{227}$

Requests for prepositioning are to be made through the Attorney General, and units larger than batallion size are not to be prepositioned without presidential approval. ${ }^{228}$ Any units up to and including a batallion in size, however, may be prepositioned even without presidential approval, whenever a need-even a potential need-might be perceived. The provisions concerning prepositioning represent a particular danger. However efficient prepositioning might seem as a means of facilitating prompt suppression of such disorders as might occur, it is also true that the prepositioning of troops can intimidate citizens and chill the exercise of constitutional rights. It should be recalled that President Grant's arguments in support of prepositioning ${ }^{229}$ were unpersuasive to the Congress in 1877 and 1878, and that Congress enacted the Posse Comitatus Act in large part because of the intimidation the congressmen believed voters had felt because of soldiers prepositioned to prevent potential disorder at the polls. ${ }^{230}$

The alarming import of the Civil Disturbance Regulations should now be quite apparent, even without any imaginative conjuring of "worst case" scenarios in which an actual military takeover might be conceived. The constitutional rule of due process prohibits any domestic application of military force except in situations of actual insurrection, where assaults specifically against the established institutions of civilian government have accomplished their goal of incapacitating those civilian institutions. ${ }^{231}$ Even though the statutory changes accomplished by Congress during the Civil War and Reconstruction Eras compromised that constitutional principle significantly, at least Congress by the Posse Comitatus Act in 1878 had required strict compliance with those amended statutes, which still require personal involvement of the President in every event. That 1878 legislation was, above all, a repudiation of the notion that anyone, even the President himself, could claim any inherent

227. 32 C.F.R. § 215.6(a)(6) (1981).

228. 32 C.F.R. \& $215.5(\mathrm{~g})(1981)$.

229. See supra text accompanying notes 156-57. Grant had explained: "The stationing of a company or part of a company in the vicinity, where they would be available to prevent riot, has been the only use made of troops prior to and at the time of the elections." G. LIEBER, supra note 152, at 6-7.

230. 7 Cong. Rec. 3851,3852 (1878).

231. See supra text accompanying notes 15-44; Ex parte Milligan, 71 U.S. (4 Wall.) 2, 127 (1866). 
authority to make domestic use of military force, no matter what emergency might be claimed. In the face of all this, the Civil Disturbance Regulations now assert broad extra-statutory authority for the discretionary use of federal troops, not only to protect federal property and functions, but also to deal with any perceived actual or potential "emergency." Such an emergency, the Regulations contemplate, might arise in the event of "calamities," an undefined term; or in the event of "disasters," another undefined term; or in the event of "civil disturbances," defined to include not only "group acts of violence" (whether or not directed at established civilian institutions of government) but also "disorders prejudicial to public law and order." 232 The judgment that such an emergency has arisen, or that there is potential that it might arise, need not be made by the President; at most a Secretary or Under Secretary of the Army might be involved, and in any event operational control will be in military hands. Moreover; even when there is no actual deployment of troops, an established Pentagon machinery of intelligence and planning is constantly in operation, watching for occasions for intervention to arise, always prepared to preposition troops or to take such other actions as might be deemed expedient.

\section{Yet Another Faulty Foundation For Military INTERVENTION}

To many American Indians, the tiny village of Wounded Knee on the Pine Ridge Indian Reservation in South Dakota has peculiar historic and symbolic significance. It was at that site in the year 1890 , when the area was still a frontier, that federal troops of the Seventh Cavalry killed at least two hundred Sioux women, children, and men in what official annals denominate a "battle" but many Indians remember as a "massacre" representative of the decades of Indian wars precipitated by the white man's westward expansion. In February 1973, this little hamlet at the crossing of two roads in a quiet valley surrounded by low hills, composed of a few churches, a trading post, an Indian museum, a gas station, and a number of small residences scattered across three square miles, was home to about seventeen families, most of whom were Oglala Sioux. A white family ran the trading post. 
There had been a few demonstrations and some violent incidents elsewhere on the Pine Ridge and nearby Rosebud Reservations during the preceding few months, in which organizers and members of the activist "American Indian Movement" (AIM) had been involved. A select force of United States marshals, called the "Special Operations Group," first organized in 1971 , had been sent to the area to enforce law and order; but by February 26 most of the marshals had been sent home. They would soon be recalled.

On the afternoon of February 27, 1973, between two and three hundred members and supporters of AIM assembled near the community of Pine Ridge. As evening arrived, they formed a car caravan and drove to Wounded Knee. Some of them were armed with rifles, pistols, knives, or clubs. When they arrived at Wounded Knee, there was a brandishing of weapons, much clamour, and some shooting into the air; the visitors, welcomed by some but not by all of the residents, reportedly took eleven white residents "hostage" and declared themselves in control of the village. Looting of the trading post and some of the other buildings was reported. About 8:30 in the evening, news of the Wounded Knee situation reached the Bureau of Indian Affairs Office in Pine Ridge, and federal authorities then set up roadblocks with passenger vehicles manned by marshals and agents of the Federal Bureau of Investigation (FBI) to prevent further entry into the Wounded Knee area. Thus began a siege that was to last seventy-one days.

The Wounded Knee incident was highly publicized, and provided opportunity for AIM to focus widespread attention upon the demands of that activist organization seeking to advance certain causes pertaining to American Indians. Publicity was in fact the purpose of the Wounded Knee occupation, and not destruction or riot, although actions such as the reported looting and the reported seizure of hostages were plainly unlawful. Because of the reports of unlawful acts, the event appropriately was of significant law enforcement concern. The level of concern it actually received, however, was distinctly out of proportion to the scale of the alleged violations of law. Beginning the morning after the takeover with a series of meetings between the United States Attorney General, the Deputy Attorney General, the Associate Deputy Attorney General, and others in Washington, D.C., Wounded Knee preoccupied the attentions of several principal officials in the national adminis- 
tration for more than two months. Although the hostages had been declared free to leave on March 1, the second full day of the occupation, and although all of them had in fact left by March 7 or 8 , the occupiers had dug trenches and prepared themselves to continue the occupation until assured of immediate congressional investigations into claimed violations of Indian treaties and into the conditions on Sioux reservations. These demands not being met, the occupiers remained for a ten week long stand-off punctuated with periodic exchanges of gunfire, covered by television crews and reporters making the occupation a major media event.

Most of the details of the Wounded Knee occupation and siege are beyond the scope of this article. The least known, because scarcely publicized, feature of the Wounded Knee incident, however, was the novel and extraordinary use that the government made of federal military resources in maintaining the siege. Although armored personnel carriers had visibly replaced civilian vehicles at the roadblocks after about two weeks, no uniformed military personnel were observed. It was not until many months later, during criminal prosecutions of some of those who had participated in the occupation, and as a result of court orders compelling resisted government disclosure to defense counsel of voluminous documentary records, ${ }^{23 s}$ that the full scope of military involvement in the siege of Wounded Knee became known; and even then, there was almost no public attention drawn to the facts.

The Directorate of Military Support at the Pentagon had been involved from the first day of the siege; the use by the federal marshals and FBI agents of Army flares and other equipment was first approved on February 28. On March 2, the Chief of Staff of the 82nd Airborne Division was dispatched to Wounded Knee as a Department of Defense "observer," and a brigade of the 82nd Airborne was placed on alert for possible deployment there. The next day an Army Colonel was deployed to Pine Ridge to coordinate logistics for the operation. On March 4, the Commander of the 18th Airborne Corps prepared for the Directorate of Military Support a memorandum entitled "Concept of Federal Military Support of Wounded Knee Opera-

233. These Defense and Justice Department internal memoranda and reports are on file with the author at the University of Puget Sound School of Law, Tacoma, Washington. 
tions." Significantly, this memorandum observed that:

[b]ecause of its isolated geographical location, the seizure and holding of Wounded Knee poses no threat to the Nation, the State of South Dakota or the Pine Ridge Indian Reservation itself. However, it is conceded that this act is a source of irritation if not embarrassment to the Administration in general and the Department of Justice in particular.

More military equipment was soon authorized for use; and on March 8 the Directorate of Military Support provided to the Vice Chief of Staff of the Army, General Alexander Haig, an assessment of a request made by the Attorney General for federal military troops to establish a twenty-five mile perimeter around Wounded Knee. The Directorate's March 8 "operational concept for operations at Wounded Knee" contemplated the use of a force of 1,000 troops from the 82nd Airborne Division. Five days later the Directorate completed a memorandum discussing three separate optional plans for the use of federal troops to end the occupation. These proposals were reviewed by, commented upon, and approved by General Haig, Army Chief of Staff Abrams and others.

While none of those extreme plans for military action was actually carried out, the Chief of Staff of the 82nd Airborne, who had helped draw up those plans after having been dispatched to Wounded Knee, remained on the scene exercising an equal voice in strategic and tactical decision making with the chief FBI and Marshals' Service officials there. Logistics functions also continued to be performed by regular military officers throughout the period of the siege. Aerial visual and photographic reconnaissance missions were repeatedly flown in Air Force planes, by crew members some of whom were regular Air Force officers and others of whom were members of the Air Force National Guard of the United States placed on active federal duty for the purpose. Ground support for the air sorties, support for the civilian personnel on the ground, instruction and maintenance regarding the military vehicles and other equipment being used, and other functions were performed by Army and Air Force military personnel on active federal duty, although they wore civilian clothes. While those who actually manned the barricades were civilian marshals and FBI agents, they used Army M-16, M-1, and M1-D1 rifles, grenade launchers, armored personnel carriers, jeeps, searchlights, and other military equipment. Regular Air 
Force aircraft and crews were used to carry Justice Department personnel as well as military officers back and forth between the nation's capital and the remote scene of the siege. In April, a force of regular Army troops was prepositioned at Fort Carson, Colorado, and held for a time on six-hour alert for possible deployment to Wounded Knee. When the episode was over and an accounting was made, it was determined that a variety of Army and Air Force trucks and sedans, with their regular military drivers, in addition to the armored personnel carriers and jeeps, had been used to maintain and support the siege, as well as 177 military rifles, almost 190,000 rounds of military ammunition, more than 23,000 flares, a dozen grenade launchers, and hundreds of tear gas grenades, mine detectors, helmets, radios, field telephones, protective vests, and a variety of other military items ranging from tents, folding cots, and stoves, to parkas, ponchos, and canteens.

The Wounded Knee occupation was indeed an occasion for diligent and deliberate law enforcement. More than that, the highly publicized episode was indeed "a source of irritation if not embarrassment" to the law-and-order Nixon administration, as the above-quoted memorandum to the Directorate of Military Support had pointed out. But it was by no stretch of the imagination an "insurrection"; nor was it even a "riot" or "civil disturbance." None of the several statutory or extra-statutory bases claimed by the new Civil Disturbance Regulations, then just one year old, as legal justification for involving the Directorate of Military Support or any military resources in aid of law enforcement was, or ever has been pretended to have been, present at Wounded Knee. No law then in force authorized the use even of military equipment, much less of military personnel, in aid of such activities of law enforcement officials. Yet for ten weeks Army Vice Chief of Staff Haig, the Directorate, and the military officers participating at the scene were actively involved in designing and adapting plans, advising, coordinating, supervising, and otherwise helping-with military personnel as well as other military resources-to execute this remarkable law enforcement enterprise. By virtue of what heretofore unheard-of authority could they have become so involved? ${ }^{234}$

234. For an enlightening critical assessment of the use of military resources at Wounded Knee, written by a Judge Advocate in the U.S. Marine Corps, see Meeks, Illegal Law Enforcement: Aiding Civil Authorities in Violation of the Posse Comitatus Act, 70 MiL. L. Rev. 83 (Dept. of Army Pamphlet 27-100-70, 1975). 
As if the broad new assertions of inherent executive prerogative made in the Civil Disturbance Regulations promulgated just twelve months earlier were not enough to remove all restraints on the discretionary use of the military for law enforcement, for this occasion the legal staffs of the Department of the Army and the Department of Defense announced yet another foundation for military intervention in civilian affairs. Acknowledging that the events at Wounded Knee could not accurately be regarded as constituting a "civil disturbance" so as to come within the scope of the Civil Disturbance Regulations, they decided (with the concurrence of the Deputy Attorney General, later appointed a federal court of appeals judge) that what was desired could be done under the guise of an obscure piece of legislation called the "Economy Act."

To anyone other than one desperate to find colorable support for something he is resolved in any event to do, the Economy Act seems plainly unsuited to such an application. It had never been put forward as support for any military involvement in law enforcement. It is doubtful that such a possibility had ever previously been conceived, by its draftsmen or anyone else. In fact, established administrative construction of the Economy Act plainly indicated that it could not validly be put to such use.

The Economy Act provides:

Any executive department or independent establishment of the Government, or any bureau or office thereof, if funds are available therefor and if it is determined by the head of such executive department, establishment, bureau, or office to be in the interest of the Government so to do, may place orders with any other such department, establishment, bureau, or office for materials, supplies, equipment, work, or services of any kind that such requisitioned Federal agency may be in a position to supply or equipped to render, and shall pay promptly by check to such Federal agency as may be requisitioned, upon its written request, either in advance or upon the furnishing or performance thereof, all or part of the estimated or actual cost thereof as determined by such department, establishment, bureau, or office as may be requisitioned; but proper adjustments on the basis of the actual cost of the materials, supplies, or equipment furnished, or work or services performed, paid for in advance, shall be made as may be agreed upon by the departments, establishments, bureaus, or offices concerned: ... Provided further, That if such work or services can be conveniently or more cheaply performed by private agencies 
such work shall be let by competitive bids to such private agencies. ${ }^{235}$

On its face, and as its name implies, the Economy Act aims at efficiency in government by making possible inter-agency transfer of supplies and services of the kind that might otherwise be procured from entities outside of government. Since it deals with the allocation of appropriated fiscal resources, the administration of the Act is overseen by the Comptroller General of the United States, who in written opinions has consistently construed it as giving the service-rendering agency no authority which it does not already have independently of the Act, ${ }^{236}$ and as applying only where the service to be performed "is a normal function of both the procuring and performing agency"2s7 independently of the Economy Act itself. ${ }^{238}$ Since none of the grounds for use of the military relied upon by the Civil Disturbance Regulations is even pretended to have been present at Wounded Knee, and since the Posse Comitatus Act categorically prohibits the use of any part of the Army or Air Force in law enforcement "except in cases and under circumstances expressly authorized by the Constitution or Act of Congress,"239 it is hardly possible to maintain that law enforcement is a "normal function" of the military departments or within their authority independently of the Economy Act itself.

Furthermore, even if its consistent administrative construction could be ignored, the Economy Act could not be viewed as an Act of Congress "expressly" providing a further exception to the prohibition of the Posse Comitatus Act. The Economy Act does not expressly refer to distinctively military resources, whether personnel or military materiel; it makes no reference whatever to efforts to "execute the laws;" and it certainly does not specify "expressly" any "cases" or "circumstances" in which law enforcement use of military resources may be made.

There was simultaneously pending in a federal court a case challenging the use of a handful of enlisted servicemen as under-

235. 31 U.S.C. $\$ 686(a)$ (1976).

236. 18 Comp. Gen. 262, at 266 (1938); 23 Comp. Gen. 935, at 937-38 (1944).

237. 32 Comp. Gen. 392, 394 (1953).

238. The Comptroller General also has pointed out that use of the Economy Act requires a written agreement between the agencies to be made in advance, 13 Comp. Gen. 234, 237 (1934). No such advance agreement was made with respect to Wounded Knee.

239. See supra note 158. 
cover investigators by the Treasury Department; but it never occurred to the government lawyers handling that case to make the assertion that the Economy Act applied, even though if that Act could justify what was done at Wounded Knee it a fortiori would have prevented the judicial condemnation of the relatively petty utilization involved in that case. ${ }^{240}$ Only in connection with the extraordinary military involvement in the Wounded Knee adventure has this fanciful interpretation of the Economy Act been advanced. ${ }^{241}$ Ten years later, the Justice

240. See United States v. Walden, 490 F.2d 372 (4th Cir. 1974).

241. Individuals accused of participating in the occupation of Wounded Knee were prosecuted for interfering with law enforcement officials "lawfully engaged in the lawful performance" of their official duties, 18 U.S.C. $\S 231(a)(3)(1976)$. In several different cases, the prosecuted individuals defended in part on the ground that the law enforcement officials were not "lawfully" engaged in the "lawful" performance of duty, for the reason that their use of the military rendered their acts unlawful. The government responded in each case by relying upon the Economy Act as making the use of the military lawful.

In the first case to reach the issue, Chief Judge Nichol flatly rejected the government's Economy Act argument. United States v. Banks, 383 F. Supp. 368 (D.S.D. 1974).

In the next case Judge Urbom, while asserting in unsupported dictum that the Economy Act made the use of military materiel (as distinguished from personnel) permissible, acquitted the defendants on the ground that, on the evidence of involvement of military personnel, "there is a reasonable doubt as to whether the law enforcement officers were 'lawfully engaged in the lawful performance of their official duties.' " United States v. Jaramillo, 380 F. Supp. 1375, 1381 (D. Neb. 1974). The government's attempt to appeal from the judgment of acquittal was dismissed without any mention of the Economy Act dictum regarding materiel. United States v. Jaramillo, 510 F.2d 808 (8th Cir. 1975).

Government counsel next put their Economy Act argument to Judge (now Chief Judge) Bogue. After displaying a hostility to the defendants which eventually led to his removal from the case, Bogue without supporting rationale endorsed the government's interpretation of the Economy Act in a ruling on a motion in limine, an opinion which he submitted for official publication (United States v. Red Feather, 392 F. Supp. 916 (D.S.D. 1975)) even though it had no effect whatever on the case; the case was reassigned to a different judge and the parties stipulated to admission of the evidence which Bogue's in limine order had sought to exclude.

Finally, government counsel put their Economy Act argument to Judge VanSickle, in United States v. McArthur, 419 F. Supp. 186 (D.N.D. 1975). Judge VanSickle in dicta endorsed the government's Economy Act contention, although without any reasoned attempt to reconcile it with the terms or policy of the Posse Comitatus Act. The operative part of VanSickle's opinion indicated that while he seemed willing to concede that the evidence might be taken to show that some of the civil law enforcement officials had made unlawful use of the military (notwithstanding the purported force of the Economy Act), he could not conclude that all of the officials interfered with by defendants had done so. Thus, he found that while the evidence of Army or Air Force use was relevant to the issue of "lawful performance," he also found "that it was not material enough to taint the presumption that 'one or more' law enforcement officers were acting in performance of their duties." Id. at 195.

The defendants before Judge VanSickle were convicted, and they appealed, sub 
Department is still maintaining, in civil litigation arising out of the Wounded Knee events, ${ }^{242}$ this preposterous pretext that the Economy Act legitimated the use made of the military at Wounded Knee. The former Nixon administration officials who are the defendants in that civil litigation have never asserted that there was any other even colorable legal authority on which they could rely.

\section{Conclusion}

Good soldiers are patriots. They are worthy of gratitude and praise. They are instruments, however, of war. Riot is not war, nor is civil disorder or even violent disobedience to law. Insurrection, or rebellion, is a case apart, where violence directed at government overthrow has, at least temporarily, attained its goal. The traditional test is whether the courts have been closed. ${ }^{243}$ Insurrection, unlike riot, is war.

nom. United States v. Casper, 541 F.2d 1275 (8th Cir. 1976), cert. denied, 430 U.S. 970 (1977). Not a word about the Economy Act appears in the court of appeals opinion; the convictions were affirmed on VanSickle's ground that the presumption of lawful performance by at least "one or more" of the civilian officers interfered with had not been overcome on the record. The only reference to the Economy Act issue was Circuit Judge Heaney's observation in his separate opinion that the Economy Act issue should be left "to another day." 541 F.2d at 1281.

Thus, no appellate court has ever countenanced the government's remarkably novel construction of the Economy Act, and no district court has done so except in immaterial dicta in the cases arising out of Wounded Knee.

Judges Urbom, Bogue, and VanSickle also each tendered their own different and peculiar interpretation of the Posse Comitatus Act, each of those three different interpretations being at odds with the interpretation thoughtfully reached and applied by the Fourth Circuit Court of Appeals in United States v. Walden, 490 F.2d 372 (4th Cir. 1974); see also Wrynn v. United States, 200 F. Supp. 457 (E.D.N.Y. 1961). Judge Bogue's futile ruling was ignored at trial. Judge Urbom acquitted his defendants notwithstanding his Posse Comitatus Act construction, and the government's appeal was dismissed. Judge VanSickle's interpretation was immaterial on the view he and the court of appeals took of the case, and the court of appeals did not address it at all.

242. Lamont v. Haig, Civil Action No. 81-5048, pending in the United States District Court for the District of South Dakota. The case was first filed in February, 1975, in the United States District Court for the District of Columbia, as Civil Action No. 75-271. A venue dismissal there was followed by a successful appeal to the United States Court of Appeals for the District of Columbia, 590 F.2d 1124 (D.C. Cir. 1978). The case was reinstated on the docket of the District Court for the District of Columbia, but proceedings were then stayed by order of that court. On February 26, 1981, that court transferred the case to the District of South Dakota pursuant to 28 U.S.C. $\S 1406(a)$. After a motions ruling on May 24, 1982, Civ. A. No. 81-5048 (see 539 F. Supp. 552 (D.S.D. 1982)), a second Amended Complaint was filed, served and answered. The case remains pending on the date of completion of this article.

243. See supra notes $62-63$ and accompanying text. 
Events of constitutional dimension in England prior to the mid-eighteenth century had marked this distinction with repeated insistence. The early American statesmen, outraged at the military law enforcement which their tradition decried as unlawful, cited it as a cause for revolution. They would not have their own government repeat the offense; thus they constitutionalized in the fifth amendment the traditional English prohibition against military intervention, by providing that no person shall be deprived of life, liberty, or property except by "due process of law." Congress, when it first came to legislate with regard to the military, carefully respected and implemented that rule.

Seventy years later, a generation of Radicals ravished due process to attain their immediate moral and political goals. When reason and a sense of restraint were restored, Congress sought to curtail military intervention by enacting the Posse Comitatus Act. That enactment, however, did not destroy the foundations for such intervention which the Civil War and Reconstruction Congresses themselves had laid. Neither has it proved effective to prevent new foundations from being laid more recently by the executive branch.

We have not for a century experienced quite such egregious military interventions, although numerous more limited instances of military law enforcement have occurred. So long as the victims of such military intervention are relatively few and unpopular, and public support for suppression is strong, such affronts to due process can be survived. But they can be neither forgotten nor excused; the English suffered Tudor and Stuart lieutenancy and commissions for three generations before they took Charles's head. When dissatisfaction becomes widespread, resort to the military expedient serves to kindle rather than quench the fire. ${ }^{244}$ Toleration of military intervention in any law

244. The use of Redcoats in Boston and elsewhere helped inflame the restless American colonists to revolution.

General Halleck, in an 1870 report quoted in 7 CoNG. REc. 3849 (1878), observed:

I have been assured by Federal civil officers that the use of troops in executing judicial process and enforcing the revenue and other civil laws seemed to increase rather than diminish the necessity of resorting to such force in civil matters. The ill-disposed become more and more exasperated at being coerced by a force which they think has been unconstitutionally employed against them, and the better disposed relax their efforts to punish local crimes, on the plea that this duty now devolves on the military.

When state National Guard troops appeared on the campus of Kent State University in 1970, what had been a diffuse series of events reacting to the American invasion of Cambodia became a concentrated and focused protest against military control of that 
enforcement circumstance ultimately portends the sort of military oppression we observe and lament in other countries today.

The promise of "due process" is empty rhetoric unless those with the requisite authority enforce obedience to what it entails. The judiciary can vindicate the law only in retrospect, as cases are made; and what is needed is the prevention of military intervention, not retrospective redress of its harm. The executive branch, in planning for future exigencies, tends to deprecate and minimize every attempted restraint on its choice of force, and to exploit every pretext to keep available the option of military means. Military officers and executive officials, when a crisis is perceived, will not parse statutes and probe legislative history, or ponder over judicial precedents; their actions will be constrained (if at all) only by their own regulations. If unlawful military intervention is to be prevented, therefore, Congress must be diligent to ensure that those regulations are made to conform to the law.

Consequently, there must be members and committees in Congress willing to make it their business, during periods of quiet when the prospect of crisis seems far away, boldly and persistently to inquire into the relevant regulations of the executive branch, and to insist that those regulations and the executive plans that are made for emergencies conform to the Congress's will. Otherwise, unlawful military intervention will not be deterred.

There must also be determination in Congress to reconsider and revise those few existing statutes which, by virtue of Reconstruction Era excesses and distortions, purport to authorize what the Constitution forbids. ${ }^{245}$

But there is more that Congress must do. The executive branch, although willful, is not usually willfully pernicious. It resorts to military expedients because those are the most effective at hand for dealing with exigencies that the executive will not, and should not, ignore. Equally effective civilian expedients for every domestic law enforcement exigency can be provided; some possibilities have been suggested above in footnote 163 . Congressional action is needed, however, to make such civilian alternatives available. Prohibitions against the military expedi-

campus, raising tensions on both sides and producing notorious tragic results.

245. E.g., 10 U.S.C. $\S 332$, discussed supra in text accompanying notes $91-98 ; 10$ U.S.C. $\S 333$, discussed supra in text accompanying notes 99-130; and several of the statutes discussed supra in note 188. 
ent, regardless how insistently maintained, cannot be expected to be effective in preventing military intervention unless adequate civilian alternatives are provided.

With Congress, therefore, rests the question whether this article might serve to inspire a revival of faith in, and faithfulness to, due process, or will merely document its demise. 